Historic, Archive Document

Do not assume content reflects current scientific knowledge, policies, or practices. 



\section{CUT FLOWERS}

A SPECIAL.TY

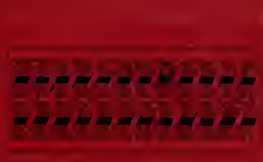

Twelfth

Annual

Catalogue and

\section{Price List}

\section{HILLSIDE}

\section{GREENHOUSES}

Discokgestanto

Florists

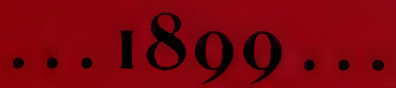

Bitgere:
Market

Gardeners

urowerisu-

Small Fruitg

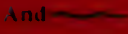

Siriall

Fruit Plants .

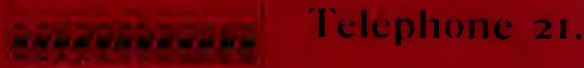

CARROLLTON,

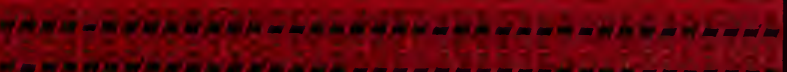

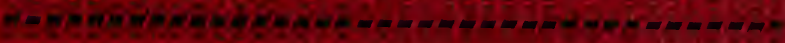

\section{Kennedy \& Farnham,}




\section{Special Collection.}

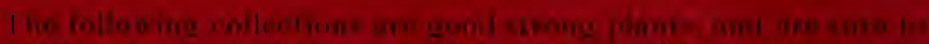

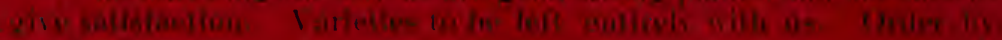
monicer

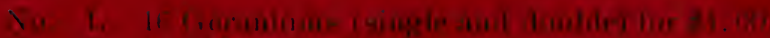

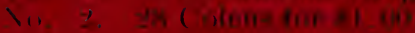

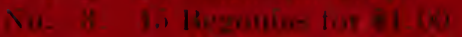

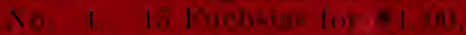

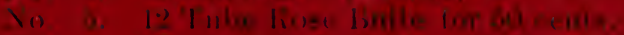

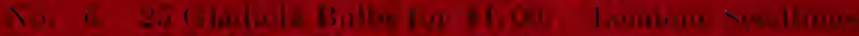

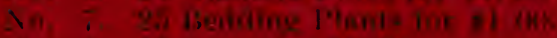

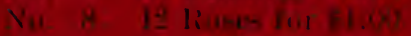

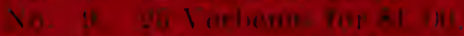

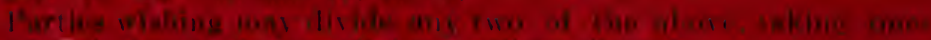

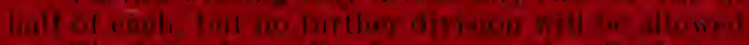

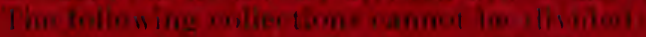

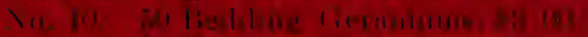

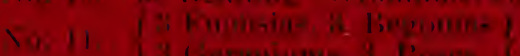

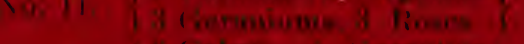

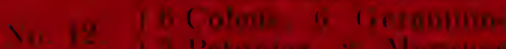

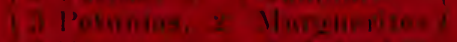

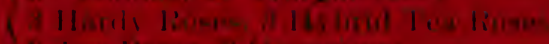

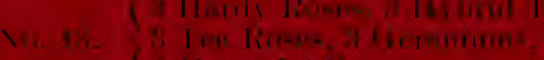

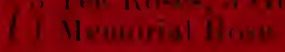

surprise collectom for of wo

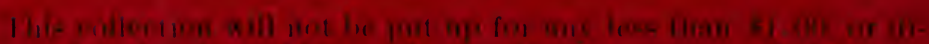

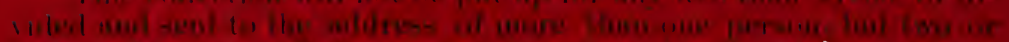

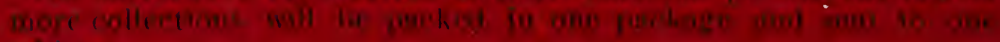

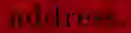

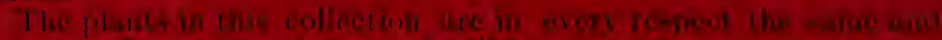

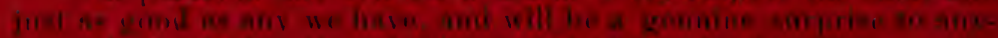

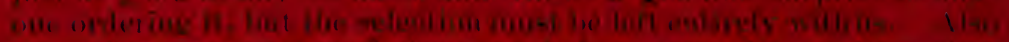

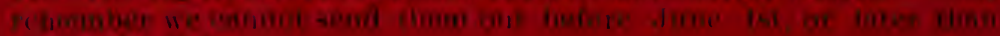

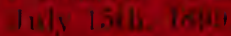

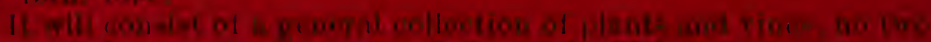

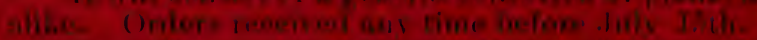

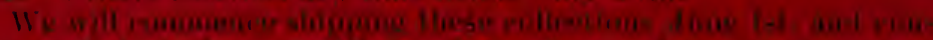

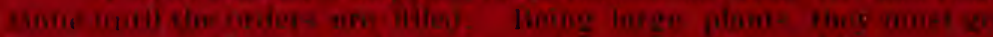

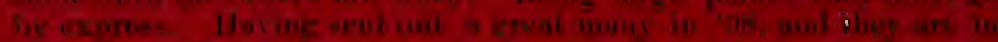

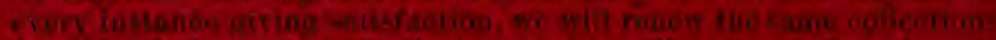

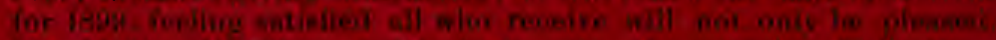

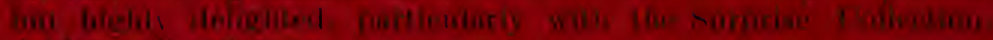

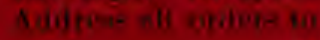

KEIVFDY \& FARYHAM, Earrolitan, Mo, 


\section{TWELFTH ANNUAL CATALOGUE}

\section{Introductory.}

\section{潘 \\ THE BASIS ON WHICH' WE SOLICIT TRADE.}

TU the sagacious buyer, dependent upon his good stock for future results, com26 petition in QUALiTY and not in prices alway's appeals. 'Jhe thinking buyer will not purchase plared-out stock and expect a healthy. vigorous progeny. To the exercise of this precaution is allied your success with plants. Strong, sturdy stocki free from hereditary disease, is an important factor and should be the first consideration-low prices notwithstanding. and to get it. the best inaterial to work from is a necessity. For years we bave made the growing of all kinds of Howers and plants a study, AND WE HAVE FOCND THAT CHEAP PLANTS ARE LSCALLY DEAR AT ANY PRICE. To sell cheap stock it must necessarily be grown cheaply. We believe there is always a demand for tirst-class stock, and to this trade we appeal. Uur plants are propagated from thoroughly matured stock and grown in very low temperature and are therefore least liable to disease. Not over-potted, they are strong. thrifty plants, established in $21-2$ and 3 inch pots. Carefully selected; in short they are fine specimens of vigorous planthood. Our list of stock comprises hundreds of different named varieties of plants, all guaranteed true to name.

\section{Low Express Rates on Plants and Bulbs.}

We are shipping by express lines to all parts of the country, plants, etc., packed in closed boxes at a reduction of 20 per cent. from regular rates of merchandise. Boxes weighing less than 100 pounds are charged at pound rates. For example: Where the general rate is $\$ 5.00$ per hundred pounds a box weighing 20 pounds would cost $80 \mathrm{c}$, where under the old rate rou would pay \$1.30. Thus you save $50 \mathrm{c}$. Packages which formerly cost $50 \mathrm{c}$ to $60 \mathrm{c}$, now at $35 \mathrm{c}$ to $40 \mathrm{c}$.

\section{Our Shipping Facilities}

Are of the best, having access to three great express companies, viz: Wells Fargo, Pacific and Adams, having sixteen express trains in and out each day.

We would also call your attention to the fact that we have telephone connection with Western Union Telegraph Co.; also connection with Missouri and Kansas long distance telephone, and access to Midland Telephone Co.'s wires, giving us direct communication to thousands of towns and homes all orer Missouri, Kansas, Nebraska and Iowa. Our Greenhouses are open day and night and telephone or telegraph message will reach us at once. Respectfully, 


\title{
Hillside Greenhouses,
}

\author{
Carrollton, Missouri. \\ (c) \\ (c) (2)
}

Read the Following Important Notice Carefully:

Names and Addresses.

IVe earnestly request our correspondents to be very particular and give their name. postoffice address, county and state in full, distinctly written. We are often in receipt of orders from customers who not only forget to sign their mames. lut also their places of residence, thus causing a delay of days and often weeks in the execution of iheir urders, and sometimes find it impossible to trace them at all.

\section{Keep a Duplicate Order.}

When you make out your order to us keep a copy of it rourself, so that you can compare the plants with it when receired. It may save both of us a great deal of trouble.

\section{Have Plants Sent by Express.}

We rould advise all parties to have their plants sent by express, as by so doing you get larger and better pliants, and we guarantee the safe arrival of all plants sent that way.

\section{Plants by Mail.}

We can and do send many plants by mail. but they must necessarily be sinaller plants, and positively cannot send out a bill of plants by mail for less than One Dollar, aud we will in no case be responsible for delays or for damage to plants sent that way.

\section{Compare Prices.}

Don't place your orders until you compare our prices with other respon- sible firms. You will find it will pay you to give us a trial, as our prices are always cheaper in comparison with the value of the plants.

\section{Size of Plants.}

To all contemplating ordering plants from us we wish you to understand that our quoted prices are forstrong, well established plants, and much larger than plants usually sent out.

\section{Reference.}

We refer to any business firm, lank or express company in Carrollton as to our responsibility.

\section{How to Send Money.}

Money should be sent by P. O. order on Carrollton, Mo., Express Money Order. Bank Draft or Registered Letter. Remittance made in any other way at sender's risk.

\section{Packages.}

We endearor to make all packages as light as possible, thereby saving you extra express charges.

The quoter prices of plants are without pots. If the pots are ranted add from 5 to 30 cents each, according to size.

\section{Substitution.}

If we should be out of any plants ordered (which is sometimes the case) we will not substitute unless ordered to do so, but will return the amount of such plants in money. 


\section{Premiums.}

We do not offer any special premiums, but will give nice plants, on all orders of $\$ 1$ and upwards, gratis. but cannot give plants on orders for less than $\$ 1$.

\section{Discounts.}

Any person sending us an order of $\$ 2$ at catalogue prices, may select plants for $\$ 2.20$.

Auy person sending an order of $\$ \tilde{a}$ at atalogue prices. may select plants for $\$ 0.50$.

Any person sending an order for $\$ 10$ at catalogue prices, may select plants for \$11.

\section{Shipping Plants.}

We can ship plants any season of the year over the following express lines: Pacilic, Adams and Wells-Fargo. No charges for packing and delivering to express company. Te personally orersee the packing of all plants. and positively will not send out any plants that are not healthy and all right.

\section{Visitors.}

We cordially invite all lovers of Howers to visit our greenhouses and examine our plants and prices.

\section{Mistakes.}

We will endeavor to avoid mistakes, but should a mistake occur in your order, will you please notify us at once and we will willingly correct it.

\section{Request.}

We would ask as a special favor, that in sending us an order you send the names of a few flower-lovi ig friends, that we mar send them one of our catalogues, thereby assisting your friends to get good plants and at the same time helping us to extend our fast increasing trade. Also please let us linow, on receipt of plants, what condition they are in and whether satisfactory or not.

\section{In Coriclusion.}

We would ask that you give this little, unassuming catalogue a careful perusal, noting the many different plants, flowers and bulbs herein offered for sale, and the prices of each, and then send us a trial order, if only for a few plants. and we are satisfied that you will ever after be a permanent custoiner of the Hillside Greenhouses.

\section{GENERAL COLLECTION OF}

\section{Abutilons.}

Boule de Neige-Of recent introduction, with dark green foliage, very large, pure white bell-shaped flowers. The very best white Abutilon. A constant bloomer, splendid for bedding out, and one of the rery best winter blooming Abutilons. Price, 10 cents.

Golden Fleece-This is without doubt the best yellow Abutilon yet attained. Flowers very large. of a very beautiful canary rellow. If you don't buy but one Abutilon get this one. A constant and profuse bloomer. splendid pot plant. always in bloom: strong. robust grower: easy to handle. Price $10 \mathrm{and}$ 1 cents.

\section{PLANTS.}

Rosetta-A rank grower, beautiful dark green foliage and a constant bloomer; flowers. rose reined pink; sure to please. Price. 10 certs.

Robert George-Of strong habit and symmetrical growth. Good bloomer; flowers large bright red with deep red veins. Price, 10 cents each.

Sour, de Bonne-One of the finest novelties ever offered. Strong grower, leares a beautiful green, banded with silver. Flower stems 8 to 9 inches long. Bloom very large, and bright orange red color. Price, 1 j cents each.

\section{Aspidistra.}

Lurida-This is a fine bouse plant; 
stands heat or rlouth; leaves 2 to 4 inches broad and 12 to 24 inches long; a dark green color. A rell grown plant; is a beautiful sight. Price, 25 and 50 cents each.

Variegata-Same as Lurida except that it has clear cream colored stripes runuing through the length of leaf. Very striking plant. Price, 50 cents each.

\section{Ageratum.}

White Cap-This variety has the same strong. compact habit of the blue varieties, with flowers of the purest white; a coustant bloomer and a splendid bedding plant: light green foliage, large cluster fleecy white flowers: fine for funeral work ; blooins summer and winter. Price, 10 cents.

John Douglas-Drarf, compact, very free flowering variety: lavender blue flowers. Price, 10 cents.

Variegata-Dware growing variety, green leaves striped white: blue flowers. Price, 10 cents. One each of the above plants for 25 cents.

\section{Alternanthera.}

These plants are valuable where high colors are wanted for foliage hed borders or erlgings: used almost exclusively for carpet bedrling, making letters and designs in flowers beds.

Acuminata Aurea-Yellow. green and crimson; large foliage; a very strong grower.

Lindenii-Leares, deep blood red, long and narrow.

Trallisii-Leares small, round and of a beautiful pulpish red color : one of the best.

Verschaffeltii-Foliage shaded from light to rlark crimson. Price, 10 cents cach, 75 cents dozen. Special prices where large quantities are wanted.

\section{Achania Malvaviscts.}

(Or Upright Fuschia.)

In this we have a beautiful plant suitable for cither bedding or pot culture; always in bloom; scarlet flowers. Price, 10 cents.

\section{Anthericum Vittatum.}

A beautiful plant with recurved, graceful foliage. The leaves are dark green, beantifully marked with broad stripes of a creamy white color. One of the best plants for the center of baskets, rases or pots. Price, 10 cents.

\section{Achelia, FI. PI.}

The Pearl-This new variety is certainly one of the most desirable hardy flowering plants grown. It is a hardy perennial, the top dying down every winter. Its flowers are perfectly double. pure white, and are produced in great profusion throughout the summer; unsurpassed for cemetery plantiug; strong plants. Each, 10 cents.

\section{Aloes.}

Very ornamental house plants with thick, fleshy leares: rery satisfactory plants, as they will stand almost any amount of rough treatment. 'Two varieties of Aloes; strong plant. Price, 10 cents each.

\section{Agave (Century Plant).}

$\Lambda$ beautiful vase or pot plant of the easiest culture, and when too large for pot plants they make a beautiful law variety.

Plain Variety-Price, 15, 25, 50 cents and $\$ 1.00$.

Variegated Leaf T'ariety-Price, 25 and 50 cents.

\section{Achyranthes.}

Well-known bedding plant of the easiest cullure.

Aurea Reticlata-Yellow, green and crimson.

Versclefumtii-Foliage and stems red.

Biemuller-Dark metal red foliage. Its stromg point is its low, spreading, sfmmetrical growth: can be trimmed down to six inches; inakes a fine border plant. Price, 10 cents each; 75 cents jer dozen.

\section{Ampelopsis.}

Veitchii-Sometimes called "Boston Ivy" and "Japan Ivy"). No picture can portray the heauty of this grand climbing plant. In the summer the foliage is a rich shade of green, but in the fall it assumes the most gorgeous tints of scarlet crimson and orange, so dazzling as to be seen a great distance. Price, 25 cents. (Field grown plants.) 


\section{Amaryllis.}

Johnsonii-A strong growing sort with flower stalk two feet high, bearing 3 to 6 brilliant flowers five inches in diameter, with a distinct white stripe in center of each petal; very fragrant. Plants, j0 cents to $\$ 1$ each.

\section{Althea.}

\section{(Or Rose of sharon.)}

A fine tall growing shrub, that once planted is good for a lifetime. Blooms when lut a slip of a plant, but eventually reaches the size of a small tree. Alwars a a srmmetrical, upright grower, well clothed with a dark green foliage, and bears every year. without fail, a profusion of large, showy, double flowers that closely resemble Hollyhocks in shape aud colors, but often larger in size. They bloom from inidsummer until frost, at a time when few other shrubs are in bloom. Fine for cemetery planting. or for grouping upon the lawn. Tha following are new double varieties of superb beauty. In Europe this is the most popular of all tlowering shrubs. No flowering tree or large shrub can approach it in majestic beauty. Three year old plants.

Rubra-Fine double red, large and brilliant. Each, 2 j cents.

Rosea-Large double pink. Price 25 cents each.

$$
\text { Alba-Blush white: very fine; } 50
$$
cents each.

\section{Aloysia Citricdora.}

(Leusnn Verberia)

A well known and deservedly popular plant on account of the delightful fragrance of its leares: extensively used in boquet work. Price 10 cents.

\section{Alyssum (Sweet).}

A useful class of plants for vases, pots or bedding out ; free flowering, of easiest culture.

Double-A variety with neat green foliage. producing spikes of pure double white fragrant flowers. Price, 10 cents.

\section{Alamanda Hendersonii.}

This remarkably fine variety is one of the best yet introduced. 'The flowers are golden.vellow. very large. finely formerl, thick and waxy-like, and tinged with brown on the outside; as an exhibition plant or bot house climber is unequalled. Price, 3 inch pots, 25 cents each.

\section{Anthemis Coronaria Fi. PI.}

(Double Golden Narguerite).

This is a most valuable plant, clear golden rellow flowers. It blooms without cessation the entire season, in winter as well as summer. It is ever covered with bloom; a tine pot plant or for bedding out. Price, 10 cents.

\section{Asparagus Sprengeri.}

A most desirable new species, especially useful to grow as a pot plant for decorative purposes or for planting in suspended baskets: the fronds are frequently four feet long. are of a rich shade of green and most useful for cutting. retaining their freshness after being cut for weeks. It will make an excellent house plant. as it withstands dry atmosphere and will succeed in almost any position. No introduction of recent years has made such a farorable impression upon us as this graceful Asparagus. We have therefore prepared a large stock of it and offer good strong plants, 4 in. pot, 25 cents: 5 in . pot. 50 cents. Specimen plants from $10 \mathrm{in}$. pots. $\$ 2.00$.

Asparagus Tenuissimus-The fine foliage of the common regetable Asparagus has always been admired. Imagine that plant transformed into a delicate climber with far finer and more filmy foliage, transforming everything it touches with the most airy and delicate greenery imaginable. It can be grown like smilax, on strings or a trellis, and will attain a great length. For boquets its foliage is simply indispensable. and will keep for several days after being cut. Plants each, 4 incli pots. 2 o cents.

Asparagus Plumosus Nanus-An elegant variety with stems tufted. The leaves or plumes are very dark green, as finely woven as the finest silken mesh, and llat in form like a fern frond. It is one of the handsomest of all foliage plants, surpassing Maiden Hair Ferus in glace, fitmess of texture and richness of color. Cut sprays retain their freshness in water for three or four weeks. Its exquisite beauty must be seen to be appreciated. Price 35 to 50 cents each. 


\section{BEGONIAS.}

The Begonias in the following list are all fine young plants, well grown, from two to two and one-half inch pots. We have also larger plants which we can furnish at 50 cents to $\$ 1.50$ each. We are making Begonias a specralty. They are easy to handle and when well grown there is nothing more beautiful.

Rubra-This is one of the finest acquisitions to our winter flowering plants ; the leaves are of the darkest green; the colors of the flowers scarlet rose, glossy and wax-like. The plants attain a height from three to five feet. First size, 3 inch pots, 25 cents each; second size, 2 inch pots, 10 cents each.

Metallica-A fine, erect growing Begonia with dark rough leaves; surface is a lustrous bronze green; veins depressed and dark red. The depression of the veins gives the leaves.a crape-like appearance. The leaf is triangular in form, much longer than wide; a free bloomer, flowers waxy white.shaded pink. Price, 2 inch pot, 10 cents, 3 inch pot, 25 cents, $\begin{array}{cc}\text { Marguerite }-\mathrm{A} & \mathrm{v} \text { a - } \\ \text { riety with leaves like }\end{array}$ Metallica, to which it is related. It grows in round, bushy form ; leaves, bronze green with purplish cast; very free flowering; large trusses of delicate, rose colored blooms. First size, 3 inch pot, 25 cents; second size, 2 inch pot, 10 cents.

Ricinifolius-So called from its likeness to the Ricinus, or Castor Bean plant. The leaf is very large, color is a rich green, with reddish marking, surface velvety. In bloom it is magnificent; the pinnacles, composed of great numbers of indiviclual pink blooms, are lifted high and spray-like, quite clear of the foliage; one of the best for winter blooms. If you don't buy but one Begonia, get this one, as we consider it one of the very best I3egonias we have. Price, 25 and 50 cents each.

Sangminea-Foliage red, with a deep- er shade on under side of leaf ; very attractive, an extra fine Begonia in every respect; sure to please. 3 inch pot, $2 \dot{0}$ cents ; 2 inch, 10 cents.

Manicata-A large leaved variety; surface smooth and dark green. The large pinnacles of pink flowers are borne high above the foliage. Price, 15 cents each.

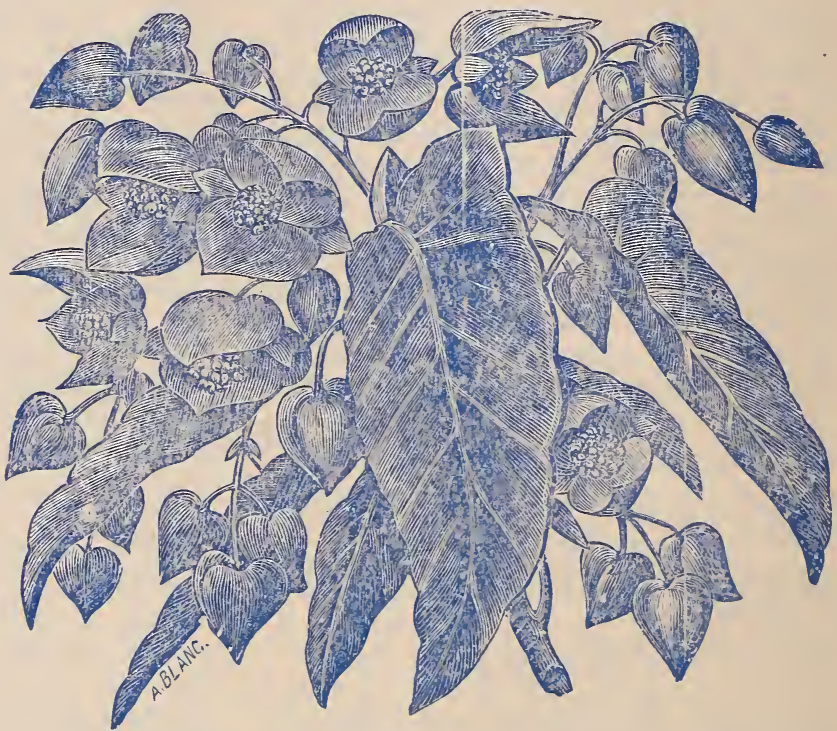

Manicretr Aura-Similar to Manicata except it has large, creamy white spots. on the leaves. Price, 25 cents.

Nigrans-This Begonia has a large and exceedingly ormamental leaf of a rich bronzy color, and of strong growth. The flowers are of a bright pink and freely produced during the winter. Price, 10 to 25 cents.

Srindersonii (Coral)-A most profuse bloomer ; color, a scarlet shade of crimson; one of the best old IBegonias. Price, 10 to 25 cents.

Wreltoniensis-Light pink ; free bloomer. Price, 10 to 25 cents. 
Weltoniensis Alba-White flowers; a good winter or summer bloomer. Price, 10 cents ; 3 inch pot, 25 cents each.

Suston's White-In this Begonia we have the finest white, both for market and cut flower work; it is a continuous bloomer, winter and summer. Price, 10 cents.

Argentea Guttata-A cross between Olbia and Alba Picta. This variety has the silvery blotches of the Alba Picta, and the form and beauty of Olbia. Olive green leares, oblong in shape, with silvery markings: White flowers on tips of the stems. Price, 10 cents each ; 3 inch pot, 25 cents each.

Alba Picta-An upright, bushy grower; leares, small, glossy green. thickly spotted with silvery white; flowers white. Price, 10 cents each; 3 inch pot, 25 cents each.

A. Picta Rnsea-Foliage same as A. Picta : flowers, rose pink. Price, 10 to 25 cents each.

Olbia-A grand variety. The leaves are bronze and from seven to ten inches in diameter. and are separated into deep. sharp points. The arrangement of the veins gives the leaf an uneven surface. The variety soon attains a heavy main trunk, which carries the branches into an erect form. It has large flowers of leınon white; one of the richest colored foliage varieties. Price, 15,25 and 50 cents each.

Vermon-This excellent variety is of unusual merit as a bedding sort, flowering fully as freely when planted out as when grown as a pot plant. It begins flowering when first planted, and continues throughout the whole season until stopped by frost. Foliage a rich, glossy green, often shaded deep bronze. Flowers are a deep red. Price, 10 to 25 cents.

Carroll (The Pink Vernon)-Same as Vernon except flowers are pink and plant not so robust, but we think a more profuse bloomer. Price. 10 to 25 cents.

Thistonii-This Begonia is a cross between B. Metallica and B. Sanguinea, having the bright red foliage and reinings underneath the leaves, and bright metallic green. shading to red, in the younger growth, on top, with the deep veinings of the Metallica and smooth, glossy leares and red stems of the Sanguinea; the flowers are a beautiful deep pink in bud, but when expanded becomes a beautiful shell pink. Price, 15 to 25 cents.

Semperflorens Gigantea Rosea-A superb variety : strong, upright; grows large flowers of clear, cardinal red, the bud only exceeded in beauty by the open flower, which is borne on a strong, thick stem. The leaves are smonth and glossy and attached closely to the main stem; both leaf and stem are quite upright growing, and forming a round, shrubby plant. Price, 15,25 and 50 cents each.

Amelia-A free growing variety of great beauty; having the wonderful habit of frequently blooming at the junction of the ribs of the leaf, imparting a novel appearance when exhibiting this peculiar character. Compact grower, flowers carmine rose in color, produced in great abundance in winter and spring months. Price, 15 to 20 cents each.

Feastii-A low, spreading variety, with round, leathery leaves, beautifully lined with red. Long stemmed pink flowers, high above foliage. Price, 15 to 25 cents each.

Otto Hacker-The plant is a strong, vigorous grower, of stiff, upright habit, with large, shining, deep green leaves. 'The flowers are borne in immense pendant clusters: color, a beautiful bright coral red. By far the most prolific bloomer of all the large flowering Begonias. Its freedom of bloom. and large, rich, showy foliage, combined make it an excellent decorative plant, and one that should find a place in every collection. Price. 2 1-2 in. pot, 10 cents ; 4 in. pot, 25 to 35 cents each.

Palmetta-The leaf is very large; will grow to over a foot in width; color, a deep, olive green. The bloom is thrown up on long footstalks to a height of 18 to 24 inches in pinnacle form; color, beautiful rose pink. A plant which must be seen to be appreciated. Price, 25 to 0 cents.

Souv. de Pres. Gaulin-Large, light green, shiny leaves, with light, silvery spots; flowers scarlet, in laroe clusters. Price, 10 to 25 cents each. 
Leonore-A compact. bushy grower, each plant forming a beatiful specimen, making it admirably adapted for pot culture. The foliage is of a bright.glossy green, and produced in abundance. 'The flowers of pure white are borne freely. well above the foliage, and have a very graceful and delicate ap pearance. Price, 10 cents.

Marvelous-Small, dark foliage (like Corai); good strong grower, flowers star shape. White with flesh shading in center. Price, 10 and 2 ó cents each.

\section{Rex Begonias.}

This class of Begonias are grown exclusively for the beauty of their foliage. 'The foliage is verv laroe and beautifully variegated with peculiar silvery metallic gloss; they are inuch used as

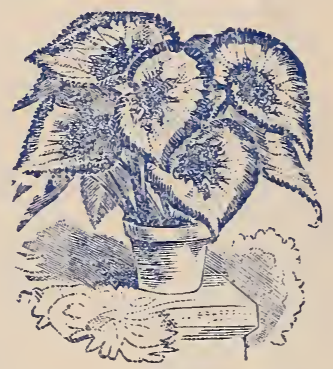
pot plants or in warden cases; they dislike our dry, bright sunshine, and thrive best in a warm. moist situation. Never wet the leares when the sum shines on them. We grow several of the most desiralıle and beantiful varieties. Price, 15 to 25 cents each. Specimen plants each $\$ 1.00$.

\section{Brugmansia Arborea.}

(Giant Ghost Flower. Angel's Trumpet or

It blooms all seasons of the vear, in a window or conservatory, or it can be cultirater in the garden during summer, or winter in a cellar or pit. 'The flowers are drooping bell-shape, of a creamy white color, and very sweet. The striking beauty of a plant bearing a dozen or more of those gigantic flowers cannot be descrilied. 'They must be seen to be appreciated. Price, 15 to 25 cents each.

\section{Bignonia Radicans.}

(Trumpet Creeper)

Fine hardy climber, bearing clusters of large, trumpet-shaped flowers : color, crimso:. shaded with orange. Foliage fine, growth rapid. 'This hardy climber is recommended, as it will grow in any soil and the most trying situations. Each, 25 cents.

\section{Bougainvillea Sanderiana.}

(Chinese (limbing P'aper l'lant)

The name of "Chinese Paper Plant" has been given to the Bougainvillea locally, possibly because of the color and lasting quality of the flowers (or bracts). The color is a soft rosy crimson, and this rariety blooms rery freely in pots, making very handsome plants in a short time. It climbs rapidly and should be trained to stakes to make a good specimen. Plants in bloom hare sold at auction in New York at from $\$ 5.00$ to $\$ 10.00$ each. Price, 1st size, 50 cents each ; $2 \mathrm{~d}$ size, 30 cents each.

\section{New Giant Browallia.}

(Ready Mily Ist.)

A most valuable addition to our list of summer-blooming plants. Most people are familiar with the old form of Browallia, and would scarcely recognize this grand nem rariety as of the same family. The flowers are indigo blue fully 2 inches across, and cover the plant when in bloom. Invaluable for summer beds of flowers or for jot plants in the winter for greenhouse and window garden. Price, 10 cents.

\section{Caladium Esculentum.}

\section{(Elephant's Ear.)}

$A$ very effective plant and suitable for either a single plant on the lawn or massing. The leares often attain the length of three feet, by trenty inches wide. The grow th is very rapid: the ground must be very rich. Extra large bulbs, 50 cents each ; medium, 25 cents each.

Fancy Foliaged-The fancy foliager varieties are beautiful plants for suminer rlecoration. They require a high temperature to bring out the colnrs to perfection. Leaves, curiously striped, blotched and spotted with white. crimson and pink. In the fall they die down, and the bulbs should be kept in the pots in a warm place. Each, 15 cts. 


\section{CANNAS.}

\section{New Large Flowering Dwarf Cannas.}

Nothing can be more effective for grouping on lawns or for large beds in parks, than these ever blooming Cannas. They commence to flower in a very short time after planting, and are a mass of gorgeous colors until stopped by frost in fall. When grown as pot plants they are beautiful specimens for the porch in summer and continue to bloom all winter if taken into the house or conservatory. At the low price that these showy plants are now offered, no one who has a lawn or yard should be without a bed of these beautiful free-blooming Cannas.

.J. Montel-One of the best Cannas grown. The foliage is a beautiful dark bronze, a color that we find so scarce among Cannas. The flowers are of large size, dark red in color, and produced in great profusion. Price, 3 in. pots, 15 cents.

Teldie Bowden-Fine bright yellow, having a touch of orange in the throat: flowers borne in immense clusters, and very free flowering; foliage, rich green ; 3 feet. Price, 3 in. pot, 15 cents.

Madame Crozy-Three and one-half feet. Immense flower heads of the deepest vermillion. These flower spikes or heads follow each other so rapidly that the plant is always in bloom. The petals are very wide and broadly rounded. It is especially in this size of individual flowers that Madame Crozy excels all Cannas. It is unquestionably the finest flower of all these new sorts. Price, 3 to 4 in. pots, 15 and 25 cents each.

Star of '91-Three feet. Foliage green, flowers large, orange scarlet, faintly tinted with golden yellow ; height only about one-half that of Madame Crozy. therefore especially adapter for pot culture. Price, 15 cents.

Florence Vaughan-The best of the new types, very large petals, large $\mathrm{flow}$. er, large spike; color. lemon yellow with bright red spots; splendid large, broad, green foliage. Height about 4 1-2 feet. Price, 4 in. pots, 20 cents each.

Alphonse Bowvier-Free and early bloomer : large petals, large flower : good open spikes: color, strong sciarlet with brilliant luster ; foliage. deep green ; height, 412 feet. Price, 4 in. pots. 20 cents each.
Chilsii (The Tiger Canna)-Foliage of a light green color. The flowers are borne in large, compact panicles; are of large size and perfect shape, with broad petals and of a bright glossy yellow color, thickly colored with crimson. Price, 15 cents.

Queen Charlotte (The Queen of Gilt Edge Cannas)-A grand, large flowered, ever blooming French Canna, with a distinct golden belt around each petal: the center brilliant orange scarlet with crimson tones. The plant is sturdy and compact, the blossoms stand well above the Iusa-like green foliage; each main flower shoot is succeeded by many side shoots, thus insuring an unbroken succession of flowers. The individual flowers are very large, the whole forming a perfect boquet, and admirably adapted to resist our summer winds. Price, 4 in. pots, 25 cents each .

Flamingo-A superb variety with trusses of immense size, nearly a foot in length and six to seren inches in diameter. The individual flowers are very large, nearly four inches across, of five even rounded form. Color deep glowing crimson, exceeclingly bright and attractive. Plant sturdy and vigorous, with massive dark green foliage in symmetrical form. rarely exceeding four feet in height. Price. 4 in. pot. 25 cents each.

\section{Grand New Giant Orchid==Flowered Cannas.}

Italia-Is of a bright oranged scarlet with a very broad, golden yellow border. the wonderfully large and handsomely formed flowers, which are produced on massive stems about 16 inches long, are set well above the foliage : the 
foliage large and heary, similar to that of Musa Ensene. Price, 4 in. pots, 25 cents.

Austria-Is a counterpart of Italia in erery way except in the color of its flowers, which are of a pure canary yellow, with a few traces of small red spots in the center of the two inside petals. Price, 25 cents.

Burbank-A wonderful new California hybrid Canna. with giant Orchid-like flowers. On the same order as Austia and Italia, but distinct and eren superior to either. Its flowers are of gigantic size, the three upper petals spreading fully seven inches; a rich canary yellow with a few carmine spots in the throat. It is of a most vigorous growth and keeps on blooming late in the season after all other sorts take on a seedy look. A magnificent novelty. Fine plants only 25 cents.

The prices quoted on these plants are for well established pot plants, not the roots or tubers.

\section{Cyperus Alternifolius.}

(Umbrella Plant.)

A grass-like plant. growing about two feet high, surrounded at the top by a whorl of leaves direrging horizontally, like the spokes of a wheel. giving the plant a curious and interesting appearance. A splendid plant for the center of baskets and rases, and unexcelled for warden cases, ferneries, or as an aquarium plant. Price, 15 and 25 cents.

\section{Clerodendron Balfouri.}

Beautiful climber, with large clusters of white and scarlet flowers. If planterl out in the open ground and kept cut back it makes a fine bedding plant, Howering profusely in the early fall. Price, 25 cents.

\section{Callas.}

Calla Ethiopica-The well-known white Calla Lily. A plant of the easiest culture. Give rich soil and plenty of water; can be had in bloom from midwinter to late spring. When they show signs of dying down in the summer, water but very little. and let them get thoroughly rlry, in which state leave them until fall, then shake off old soil ancl re-pot. but water sparingly at first. Price, 15, 25 and 35 cents each.

\section{Cissus Discolor.}

(Trailing Begonia.)

A climber with very beautiful foliage, deep velvety green. mottled with white on the upper surface; under side of a deep reddish purple. For trailing over the side of a window box or grown on a trellis it is one of the most odd and attractire plants. Price, 10 cents each.

\section{Cuphea.}

(Cigar Plant.)

Platycentra-Of low habit and completely corered with crimson and clark red, tube-shaped flowers the entire season; a fine bedding and winter blooming plant. Price, 10 cents.

\section{Cineraria.}

Magnificent and indispensable flowering plants for spring decoration for the conservatory or window garden. The flowers measure 1 to 1 1-2 inches across, are of white, blue, violet and crimson shades, corering the plant with a.sheet of bloom. Price, 15 to 25 cents.

\section{Cyclamen Persicum.}

There are few plants more showr than the Crclamen, blooming in the winter

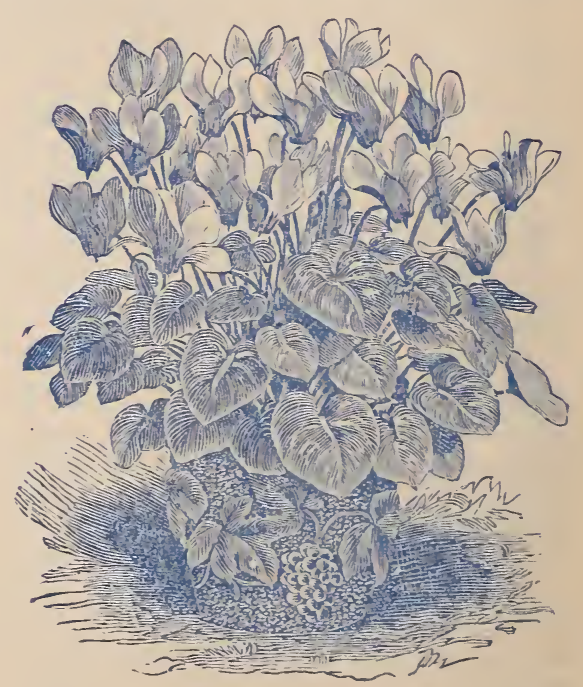

and spring. Flowers of peculiar shape, on long stems. of rarious colors ; beautiful foliage. Price, 25 to 50 cents.

\section{Clematis.}

Jarkmanii-The flowers when fully expanded are from 4 to 5 inches in dianeter: intense violet purple, with a 
rich velvety appearance; distinctly veined. It flowers continnally from July until cut down by frost; perfectly hardy, a rampant grower, strong plants. Price, 75 cents.

Paniculata-One of the finest hardy species in cultivation. Of robust habit, climbing about 12 feet high, and covered from the oround to the summit with pure white, deliciously fragrant flowers, so freely produced as to completely hicle the foliage. In September the flowers are followed by pretty seed pods of bronzy red. Three year old plants. Each 35 cents.

\section{Coleus.}

Of these beautiful tender bedding plants we have a fine collection of 24 of the most striking colors to be found in the Coleus; every one of them a gem. Price, jeents each ; 0 cents per dozen.

\section{Convallaria.}

(Lily of The Valley)

One of the most charming of our spring flowering plants, whose tender stems, set with their tiny bells, diffusing a delicious odor, having rendered it a universal farorite. Roots delivered until April and after September 1st; cents each; 50 cents a dozen.

\section{Calycanthus.}

(Or Sweet Scented Shrub.)

Flowers purple; very double and deliciously fragrant; blooms at intervals during season; old and much esteemed. Price, 2õ cents.

\section{Coreopsis Lanceolata.}

(The perpetual Golden Coreopsis). This plant is of the highest possible ralue. Gires a constant succession of the most brilliant golden yellow flowers as large as a silver dollar, growing on long. slender stems two feet high. The beauty of these flowers is unequalled by any yellow flower that we know of, and the long stems fit them for cutting for the house. There is, perhaps, no other perennial so valuable for summer cutting. Price, strong young plants, 10 cents.

\section{CARNATIONS.}

This is one of the most useful and beautiful of cultivated flowers, it being the only rival of the Rose. They are very fragrant, beautiful and free bloomers. They are of the easiest culture and should be planted out as soon as possible in the spring. If intended for winter flowering they must be pinched back every two or three weeks until the first of September. Take up and pot about October 1st.

Mme. Dicaz Albertina-This is an ideal Carnation of the very laroest size; very full and double; a delicate flesh pink, with a strong clove fragrance; has exrellent keeping qualities. Price, 15 cents.

Fred Dorner-Flower extra large, selflom less than three inches across, a constant free bloomer and vigorous grower. Une of the best red Carnations. Price, 10 cents.

Wm. Scott-Delicate light pink, with finely fringed petals; flowers of large size on long stems that hold the flower erect. A splendid keeper, lasting a long time when cut. Each, 10 cents.

Meteor-Deep brilliant crimson. Medium sized bloom, 21.2 to 3 inches, on a firm, strong stem 14 to 18 inches long. Plant a free, vigorous grower, clean foliage, aud good,free bloomer. Each, 15 cts.

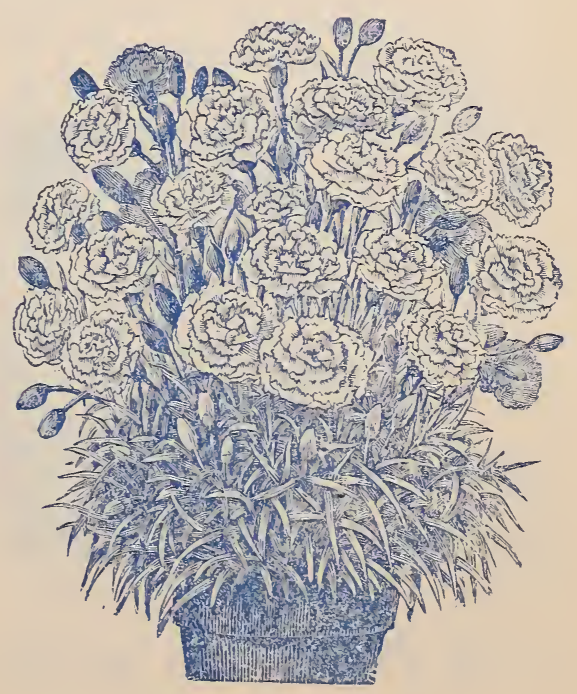


Helen Keller-The finest of all the "flakes;" catches the popular fancy everywhere. Purest white heavily penciled in scarlet and carmine. Throws up slender, stiff stems, which carry large flowers. This variety is giving better satisfaction each year and is a gem in the Carnation family. Each, 10 cents.

Gold Finch-A beautiful yellow, penciled and edged pink; of good habit and easy growth. This variety is steadily growing in popularity. Price, 15 cents each.

Mary Wood-Strong, dwarf grower, good bloomer; extra large white flower; does not burst its calyx; stems very strong. Price, 15 cents each.

Two Fine New Carnations.

Jubilee-Color intense scarlet. Said to be the richest shade of all the varieties. It is a persistent bloomer, and plants are very strong and vigorous growth. Price, each, 20 cents.

Flora Hill-A most desirable white variety that is largely grown by florists on account of the profusion of bloom with which the flowers are produced. The introducer claims it to be the most prolific bloomer of the Carnation family. Price, each, 20 cents. One each of the two new varieties, 35 cents.

One each of the above 9 sorts for $\$ 1$.

\section{CHRYSANTHEMUMS.}

The Queen of Autumn.

There is no flower that thrives as well, with as little attention as the Chrysanthemum. The cultivation is most simple, growing freely in any rich, moist soil in a sunny situation. On the approach of warm weather set the plants two feet apart and keep them well pinched back until the middle of July, after which buds form. Take up about August 15th, and put in large pots or boxes with rich soil, water thoroughly, shade for a few days; give liquid manure about once a week; keep them away from frost or cold winds, but do not bring into fire heated rooms. We only offer a few of the very best and will fill all orders promptly. Having discarderl ail but the very best, we can recommend the following varieties as being exceptionally fine.

Eugene Dailledouze-Large, full, double, glowing in color, stiff stem and good foliage, and above all a free, easy grower. There is nothing brighter or clearer among yellows. The center is folded close like Kioto, the petals are broad and incurving, and of great substance. It is full to the last degree of great lepth, and per-

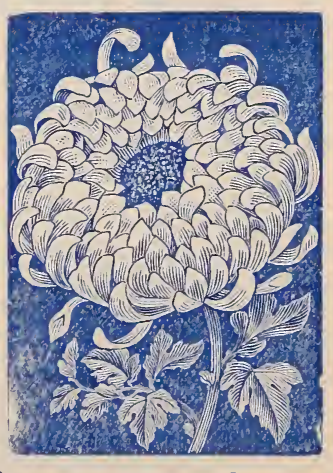

fect in form. Price, 10 cents each.

Ernest Asmus-Flowers of massive size, plumed and reflexed. The color is a rich chrome-shaded amber; habit of plant excellent; early. Price, 10 cents.

The Queen-One of the very tinest whites to date; it excels all in purity. extra large in size, of beautiful half globular form with broad, incurved shapely petals of great substance ; $q$ rowth robust and large; smooth, heary, (leep foliage; carries flowers erect on stiff stem; a grand show flower and promises to be very profitable for commercial purposes. Opens October 15th. Price. 10 cents.

Niveus-A grand show white, center irregularly incurving, with outer petals reflexing nearly to the stem. Constitution robust; foliage large and abundant, while keening qualities are unsurpassed. Without doubt one of the best. Price, 10 cents. 
Mrs. Jerome Jones-Creamy white. incurved. high rounded flower; large and fine form; one of the lost of all whites. Price. 10 cents.

Challenge-A late variety, being in full perfection towards the end of No. rember, although in grand condition and readr for cutting three weeks earlier; the shape being a perfect globe of brightest gold. deptb and width being equal; very strony stem and good foliage: somewhat dwarf in habit. Price, 10 cents each.

Lily Bates-Very large. perfectly double, clear, bright, rich pink, petals broad and flat; new and distinct form. Price, 10 cents.

Trarban-Pink. very large. fuliflower, deep in color and long, broad petals, outer of which reflex; those of the center recurre, making a superl, sbow bloom. Price 10 r'ents.

Golden Gate-Japanese origin. Lovely chrome-rellow. with whorled center; large, flat flowers with spreading petals. A magnificent variety. taking first prize of certificates wherever exhilited. Price, 10 cents.

Kioto-Bright yellow: broad petals beautifully incurved and interlaced; large and of exquisite form. very distinct. Price, 10 cents.

Elcme-Early: pare white, tinges to pink with age: bushy halit: one of the very best whites. Price, 10 cents each.

I.01\%y-Second early. An exquisite white. absolutely pure. The flower is quite regular in form, very large and flat. the length of petals grarluating to the center. Price. 10 cents.

Major Bonuaffon-Grand incurred rellow of largest size. full to the center. stem dwarf and erect. Special Columbia Medal at Chicago: certificate and first prize, Indianapolis. Price, 10 cents.

Mutual Friend-Early. A reflexed pure white, of good size, from 7 to 10 inches in diameter. great depth: no center; stiff stem. heary foliage and great keeping qualities: of medinm height. Price, 10 c'ents.

G. Tr. Child.s-The best early crimson in commerce. Flowers large, reflexed: color. deep rich velvety crimson : borne on strong stiff stems. Price, 10 cents each.
Miss Mimnie Wanamaker-White, of the largest size; a variety in great demand: extra good for cutting or exhibition. Price, 10 cents each.

J. R. Cramp-Very large. incurved, magenta. Price. 10 cents.

Mis. Perrin-The nearest approach to the true pink so long sought. Stiff stems, short neck, ornamental foliage, flower of globular form ; incurred, full, color rose pink within, glistening pink without. Price. 15 cents each.

Price per dozen, $\$ 1.00$.

Cirysanthemum Frutescens.

(Paris Daisy or Marguerite.)

It is a fine florist flower. A gool winter bloomer as well as for sumimer. Price. 10 cents.

Mad. Ferfacillon-The foliage of this variety is very finely cut. The flowers are the same as found in the old variety, single white with yellow disc. The prettiest Paris Dais in existence. Price, 10 cents each.

Ox Eyed Daisy-The well-known hardy field Daisy: flowers 2 to 2 1-2 inches across, showing large sellow disc in center : horne on upright stems 18 to 24 incles high. Price 10 cents each.

\section{Dahlias.}

Within the last year or two wonderful interest has been revived in the Dahlias. making them a strong rival of the popular bedding plants, the Geranium and Canna. having already out. rivaled the Chrysanthemum. We have a fine collection of popular colors.

Corlineal-Rich crimson scarlet.

Beanty-Snow white.

Asic-Peach pink; early.

Exquisite-Orange, shaded scarlet.

Maroon Beanty-Purplish Maroon.

Canaivy Bird-Large, free canary rellow.

Price, 15 cents each : set of 6,75 cents.

\section{Dicentra Spectabilis.}

(Bleeding Heart.)

Has heart-shaped, deep pink flowers, a clozen or more being borne on a long, drooping raceme, a foot or more in length, perfectly hardy. Price 2 s̃ cents.

\section{Dracaena Indivisa.}

One of the most popular plants for house decoration or for the center of 
lawn vases. As a single specimen plant for a jardiniere in a hall or drawing room it has no equal. It is more graceful than a Palm, and because of its slender, drooping leaves is often called a "Fountain Plant." It grows rapidly, is adapted to the close atmosphere of the house. Price, 25 and 35 cents each.

\section{Duetzia Gracilis.}

A perfectly hardy shrub of low growth, being completely covered with flowers early in spring. Price, 25 cents.

\section{Euphorbia Splendens.}

(Crown of Thorns.)

A curious plant with few leaves, and closely covered with long spines; bright scarlet flowers, borne very freely. Price, 10 to 25 cents.

\section{Eupatorium.}

Triste-One of the most valuable of white, winter flowering plants, of tall habit. Price, 10 cents each.

\section{Echeveria.}

A genius of succulent plants, both novel and interesting. They are useful either as pot plants, for decorating purposes or for bedding out in summer. Being a native of arid countries, they thrive best if planted in a dry situation. Price, 10 cents.

\section{Fuchsias.}

Earl of Beaconsfield-Corolla pink; tube and sepals white ; very free flower-

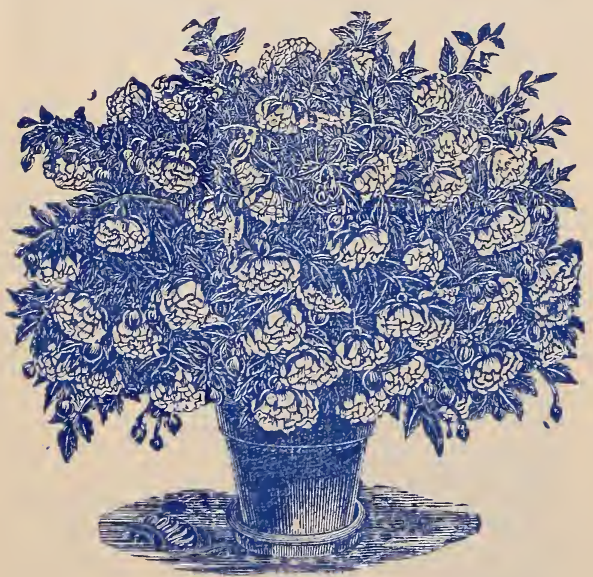

ing, mammoth bloom; the very best winter bloomer. Price, 2 in. pot, 10 cents; 3 inch pot, 20 cents.

Plienomencil-Largest Fuchsia that has yet come to our notice; short tubes and sepals of a bright, rich, reddish crimson color; corolla very full and double; of a beautiful azure violet. flaked with red. Price, 20 cents.

Speciosa-Very hardy, easy to grow ; a free bloomer; pale, salmon pink. An old variety, but one of the best. Price, 10 cents.

Black Prince-Large, expanded, bellshaped corolla, of a reddish color; tube and sepals crimson; one of the best bloomers; single. Price, 10 cents.

Charles Blanc-Corolla rich amaranth, tube and sepals light rosy pink; a splendid, robust grower. Price, 10 cents each.

Convent Garden-Corolla rose; tube and sepals white; very profuse bloomer. Price, 10 cents.

E. G. Hill-This is undoubtedly the most perfect and double white Fuchsia ever raised. The short tube and sepals are a bright, rich, reddish crimson color ; corolla extra large, full and double flower ; of large size; in all save color, it is like Phenomenal. Price, 20 cents each.

Mad. Tanderstraus-Tube and sepals coral-red, corolla large, double and pure white; one of the besi Fuchsias in our collection. Price, 10 cents.

Molesworth-White corolla, crimson sepals; double. Price, 10 cents each.

J. Rosain-Double, very large scarlet tube and sepals, corolla violet. Price, 10 cents each.

\section{Feverfew.}

(New Dwarf.)

Little Gem-One of the best continuous white flowering plants ever introduced. It rarely ever exceeds 20 inches in height. and flowers from. June until frost. One of the best plants for cemetery use or for cut flower work. Price, 10 and 15 cents.

\section{Farfugium Grande.}

(Leopard Plant.)

Showy leaves of dark, glossy green, with numerous blotches of rellow; very ornamental ; excellent plant for ferneries or pots. Price, from 4 in. pot, 25 cents.

Ficus Elastica.

(India Rubber Plant.)

Fine old plant which is becoming very 
popular, not only in the greenhouses, but as a decorative plant for the drawing room or flower garden. Its thick, leathery leaves make it specially valuable, in consequence of it doing perfectly well in the dry air of dwelling rooms. Price, 25 cents to $\$ 1.00$.

Natida-One of the small leared va- rieties. Price, 25 cents to $\$ 1.00$.

\section{Gladiolus.}

These beautiful flowers are indispensable in every garden, for they are in full bloom from the middle of summer until frost; mixed, extra fine; all new. Price, large select bulbs, 5 cents each; 6 for 25 cents.

\section{GERANIUMS.}

\section{Three Fine Singles.}

Majestic-We still claim that Majestic is the thriftiest grower and most profuse bloomer on the market today. Flowers of striking sub-scarlet veined crimson, overcast by a peculiar silvery sheen, which adds greatly to its beauty; trusses are 5 to 7 inches across, florets being considerably larger than a silver dollar, and borne on long foot stalks well above the foliage. The foliage is very heavy and glossy, deep green, serated edge, and very dark zone ; a very beautiful plant. Price, 2 1.2 in. pot, 20 cents; 4 in. pot, 30 cents.

Crabapple-One of the best Geraniums of recent introduction. Good strong grower, and earliest bloomer of them all. The flowers are clear white suffused with heliotrope pink. Price, 2 1-2 in. pot, 15 cents ; 3 in. pot, 2 ó cents.

Incandescent-A seedling from Kate Patterson, which we have

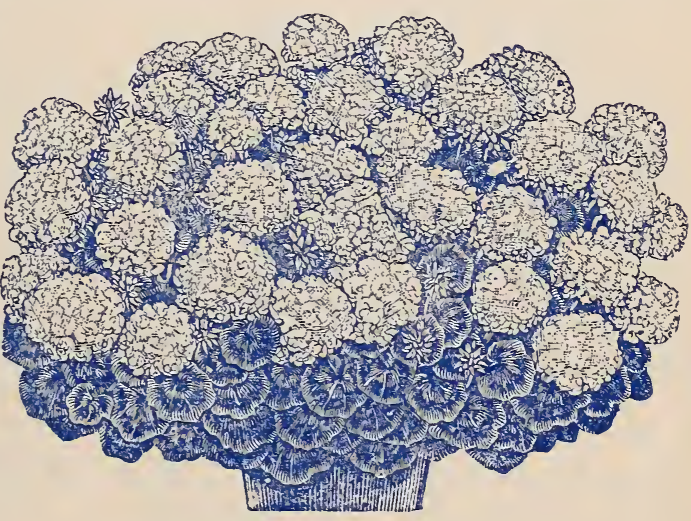

ALPINE BEACTY. grown in our trial fields for several years. It grows tall and strong, has good folıge of olive green, with dark zone; flowers of pure shell pink, a shade very much sought. Price, 2 1-2 in. pot, 15 cents; 3 in. pot, 25 cents.

One each of the above three fine plants for 40 cents.

\section{Best Six Double Bruants.}

(Price 10 cents, except where noted.)

Alpine Beauty-Very dwarf, with stiff, neat foliage, the flower stems long and stiff. Both floret and truss are of unusual size, and it has stood the sun finely, proving a good bedder. We consider this the finest double white up to date. Price, 15 cents each.

Fille de Poitairs-There is nothing finer than this in the Bruant race. Color, rosy scarlet, very clear and bright, trusses very large, composed of enormous florets, nearly three inches across, and of the peculiarly beautiful form of
Beauty Poitevine. Very free, producing an elegant effect when massed.

Madame Jonis - A very beautiful variety ; color, bright rose at the center, with a wide border of flesh color or white, florets of the largest size, semidouble and flat in form. A grand addition to the doubles.

Beauty Poitevine-Very large, semidouble flowers, borne on immense trusses. Free bloomer, either as a pot plant or a bedder. It has no equal of the color, which is a brilliant salmon, very clear at the borders. This might well have been called "Salmon Bruant." 
as it is identical in every way but color. Price, 10 cents each.

Leonard Kelway-Glowing carmine: vers bright and attractive, the petals showing a peculiar gloss: color as fine as S. A. Nutt, while the truss is much larger; a grand addition to the dark reds, which are always in great demand.

Peter Crozy-A cross between the Iry Geraniums and the Zonals. The foliage shows the blending of the two races, having the form of the Iry and the substance and size of the Zonals. The flowers are brilliant scarlet. borne in the greatest profusion, the trusses measuring six inches across, and the indiridual florets two inches. The habit is dwarf and compact; the flowers are semi-double and last a long time.

\section{Best Seven Single Bruants.}

(Each 10 cents except where noted.)

Protee-Flowers very large and freely produced in immense trusses. Color, silvery lilac, white shadings changing to silvery pink. A splendid sort.

Mme. Chas. Molin-Trusses and florets enormous, color, clear, bright salmon, white eye. Remarkable for the beauty of the trusses, also for its lovely color. Plant. semi-dwarf, zoned in black. and very fine in bloom.

Madame Alfied Wam-The largest flowered of all Geraniums. This is not only the largest flowered, but a sturdy grower. A magnificent bedding variety. The trusses are of extraordinary size, the florets by actual measurement being two and one-half inches long by two inches wide. of almost pansy form. 'The color is a soft sub-scarlet. lower petals changing to salmon in the center. which is deeply reined crimson. Price, 15 cents each.

Herla-Crimson-scarlet or carmine. of the lovliest sharie; flowers very large and finely formed. One of the finest of fancy reds.

Grustrive Moreun-Trusses exceptional15 large. florets of line size; color soft, silvery lilac. lighter at the center. A line French variety, of unusual merit in this color.

Mis. E. G. IIill-Florets two hy twoand one-half inches. The center of each petal is soft. light salmon, hordered with rosy salmon and reined (leep rose. Fre- quently throws six petals; Bruant's novelty last year; not to be confused with the old rariety of the same name: resembles a rare Begonia bloom more than a Geranium.

1T. Emiel Bare-Large, finely formed florets. borne in trusses. Vermillionred flowers: fine for massing; single flowered; a rery attractive and showy variety.

The above 16 Geraniums, including our 3 fine seedlings, for $\$ 1.50$. Any of the abore 13 Brriants in 4 inch pots, at 25 cents each.

\section{General Collection of the Very Best Old and New Varieties.}

The following double Geraniums are 10 cents each, or $\$ 1$ per dozen:

Benjamin Schroder-Light green foliage that is very bright in color: Hower extremely large : of soft. rosy piuk color, with distinct white blotches on the upper petal: of satiny texture; petals slightly recurving.

Hetheranthe-Quite similar to Bruant sare that it is softer shade of color, while still rery brilliant. Another grand variety.

Glorie de France-Laroe. round. individual flower; color, white. with a dark, distinct, salmon red center.

Asa Gray-Light salmon orange : one of the best old varieties.

White suan-A perfectly double. pure white variety, the best of its class: it is remarkably free flowering. and in its season a perfect hall of snow white flowers.

Double Grant-Brilliant scarlet: immense size: strong grower.

. John Heron-Plumb-purple flower.

Bastien la Parp-Bright salmon, tinted with orange; beautiful.

Negro-Darkest of all: trusses well formed, of a clark, velvety red color of a rery rich tint: undoubterly the darkest red out.

1. Crimurger-Large trusses of brilliant led. Plant free blooming and good habit.

Burrantii-Semi-rlouble. Color of the flower a vermillion red. of a most pleas ing shape. The flowers are absolutely perfect in shape, contour and make-up): trusses exceptionally large and borne in immense spherical balls, often measur- 
ing eight inches in diameter. The best scarlet bedder extant.

Contrast-Maroon slịaded riolet; dwarf, compact growth; good foliage: fine bloomer.

Little Gem-Of very dwarf habit. Similar in color and style to Double Grant.

\section{Single Geraniums.}

The following single Geraniums are 10 cents each. or $\$ 1$ per dozen :

Sonrenir de Mirande-The greatest novelty in New Geraniums that has appeared for a number of years is undoubtedly Souvenir de Mirande. It has round florets: upper petals cream white with a distinct rosy-pink border; lower petals salmon-rose. streakeri with pure white; a most norel color.

A. Dandett-A splendid old variety; good foliage : color of flower pure white, salmon-red center.

Qreen of Belgium-Without doubt the finest single white ever produced: pure show-white. enormous truss; a heautiful plant.

Rer. Athinson-Deep crimson.

I)czzler-Scarlet : white eve.

Grount-Large, scarlet truss.

Fite Pattison-Rich, deep orange, orerlaid with buff; entirely distinct from any other variety.

Bernty of Loniseille-Rich, dark velvety crimson; sure to please.

Glorie de Priterime- Large trusses of immense size. Rich red, shaded orange. with white eye. Very rigorous and free.

Chaplin-Habit semi-dwarf. Small foliage nicely zoned. Large florets. semi-double; of brilliant red. shadling to white center.

Mad. de la Rue-Color. a beautiful shade of orange s'arlet.

Blanche Monlas-Very light salmon, erlged about the petals with white. One of the finest of the lighter Bruants.

Bintus-Very large: carmine purple.

L.ycta-Fine scarlet: one of the best plants for helding we have ; very bushy.

Besides the above we have many others at 10 cents each or $\$ 1.00$ per dozen : 16 Geraniums, our selection, for $\$ 1.00$.

\section{Variegated Geraniums.}

Black Douglas-Very dark maroon zoned, on golden-y ellow ground; salmon flower; single. Price, 10 cents.

Distinction-Deep green; serated edge, black zone; a fine plant. Price. 10 cents.

Goliah-Green, edged white, with dark zone. Price, 15 cents.

Happy Thought-Deep green, large, creamy-rellow blotch in the center. Price, 1 ó cents.

Monntain of Snow-Deep green, margined white, strong grower. Price, 10 cents.

Mad. Salleroi-This is an entirely distinct variety, with leares from one to two inches in diameter. The center of each is of deep, olive green, with broad margins of pure white. Price, 10 cents.

Mrs. Pollock:(Golden Tri-color)--As an ornament for the parlor or conservatory, nothing yet excels this beautiful plant. The flowers are dark scarlet : the ground color, or rather the disc of the leaf, is green; next comes a zone of bronzecrimson margined scarlet; then a belt of lighter green, the margin of the leares heing a clear yellow. Price 15 cents.

Hary Hoover-Serated leaf, yellow base. surrounded with dark zone, vining habit, single scarlet flower, a profuse bloomer: Price, 10 cents .

\section{Ivy Leaf Geranium.}

(Double Elowering.)

Congo-Large and compact truss: flower round and rery double; good form, beautiful rosy lilac. Price. 10 cents.

Somr. de Chas. Turner-One of the handsomest Iry Geraniums ever introduced. Florets two and one-half inches, in trusses six inches across. The color is deep, bright pink, approaching scarlet in color; the upper petals feathered maroon : quite double. Awarded numerous certificates. Price, 10 cents.

Glory of the Garden-One of the finest. Flower a beautiful shade of crimson pink; full, roseate shape;' a rery rank grower. Price, 10 cents each. 


\section{Scented Geraniums.}

Rose Scented-Large leaf. Price, 10 cents.

Rose Scented-Cut leaf. Price, 10 cents.

Balm Scented-Price, 10 cents.

Oak Leaf-Price, 10 cents.

Mrs. Taylor-A very fine rose scented variety with large scarlet flowers; a very free bloomer. Price, 10 cents.

Nutmeg Scented-Price, 10 cents.

Lemon Scented-Small leaves, growing erect; of delicious lemon fragrance; one of the most pleasing varieties. Price, 10 cents.

\section{Hydrangeas.}

Otrsko-Having tried all the $\mathrm{Hy}$ drangeas in commerce we find that Otaska is the best, having discarded all the balance. It is a splendid variety from Japan. Flowers bright pink, enormous clusters; of easy culture. Price, 10 to 25 cents ; 8 inch pot plants, 50 cents.

Hydrangea Paniculata Grandiflora-This is the most valuable hardy shrub in cultivation. It attains the height of three or four feet and is perfectly hardy in all parts of the country. The flowers are white, borne in immense pyramidal panicles nearly a foot in length. It commences flowering in July and continues until November. This is very desirable for cemetery planting. Price, strong plants, 25 cents each; extra strong, 50 cents each.

Honeysuckle.

Belgic-Blooms throughout the season; flower large, red and yellow; very fragrant. Price, 20 cents.

Chinese Twining-Blooms at intervals through the summer and retains its foliage late in winter; flowers nearly white, fragrant. Price, 10 cents each.

Japan Golden Ivy-A handsome and very desirable variety, with the foliage beautifully netted or variegated with yellow; very fine. Price, 10 cents each.

\section{Heliotrope.}

A favorite and free flowering tribe of plants, equally good as summer bedding plants, or for pots in the house during winter.

Snow Wreath-A very fine variety, being the nearest approach to white. Price, 10 cents.

$$
\text { Garfiell-Purple. Price, } 10 \text { cents. }
$$

\section{Hoya Carnosa.}

(IVax Plant.)

A climbing plant, with thick, fleshy leaves, bearing umbels of beautiful flesh-colored, star-shaped flowers, one of the best plants for house culture, as it stands the extremes of the heat and cold better than most plants and is not injured by neglect. Price, 25 cents each from 4 inch pots.

\section{Hibiscus.}

Carminatus Perfectus-Large, single flowers in great abundance; scarlet, shaded to rose. Price, 25 cents each.

Carminatus-Double, high full center, round as a ball; color, scarlet. Should be in every collection. Price, 25 to 50 cents.

Aurincatii-Large, double, orange color, overlaid with buff. Price, 10 to 50 cents.

\section{Iris.}

The magnificence of these splendid new Irises surpasses description in beauty, size of flower, richness of coloring; they are grand. The flowers are enormous, averaging from 6 to 8 inches, and of indescribable and charming hues and colors, varying like watered silk in the sunlight, the prevailing colors being white, crimson, rose, lilac, lavender, violet, buff and blue, each flower usually representing several shades. The Iris is perfectly hardy, and flowers in profusion for a period of four to six weeks in June and July. We have the following colors: Lilac shaded purple, buff, cream veined yellow, royal blue, light blue, white edged and veined blue, yellow shaded bronze. Price, 25 to 3 i cents each. Plants can be had from March l'st to May כ̌th.

\section{Ivies.}

IIelix-The well known English Ivy. Price, 10 and 15 cents.

German-Smooth, glossy, light green leaves, a very rapid grower. Price, 10 cents. 
German I'y, T'ariegata-A variety of German Ivy with variegated leaves, green and white. Price, 10 cents.

Kieniluorth-A pretty. drooping plant, with small lilac flowers; fine for baskets or vases. Price, 10 cents.

Grave Iry (or Myrtle)-The wellknown hardy Ivy for cemetery planting; leares, a smooth, dark, glossy green. Price, 10 cents ; 3 for 25 cents.

\section{Impomoea Noctiphyton.}

(Hoon Flower.)

A handsome and useful vine of rerr rapid growth. Leaves large, smooth, dark green, heart-shaped and pointed; flowers large, color white, with five pointed stars extending through the petals; a strong grower. Price, 10 to 15 cents each.

Impomoea Paniculata-A tuberous rooted variety; stroug, rapid grower, literally covered with pink flowers. Strong roots, 25 cents.

\section{Impatiens Sultani.}

The prettiest and most distinct flowering plant that has been introduced for a long time, always in bloom and a perfect mass of glistening, rose-scarlet flowers. For table and house decoration, and for bedding, it is magnificent. Price, 10 cents each.

\section{Jasmines.}

Grandeflorum (Star Jasmine)-Pure white, star-shaped flowers; trailing habit; free flowering: very fragrant. Price, 10 and 25 cents.

Rerolution-A half climbing variety, with thick evergreen foliage; flowers bright yellow ; very fragrant. Price, 10 and 25 cents.

\section{Lantana.}

Mrs. Host-Lilac and yellow: a very strong grower. Price, 10 cents.

Snow Ball-This is the very best white variety. Price, 10 cents.

II. Schmidt-Vermillion purple, passing to brilliant yellow. Price. 10 cents each.

Jacques Winot-The beautiful red flowering sort, fading to a beautiful deep orange yellow. Price, 10 cents each.

\section{Manettia Vine}

Manettia Bicolor-A very pretty, rapid growing, twining plant, producing tubular flowers from one to two inches in length, being a flame color, tinted with bright yellow, making a plant of great beauty: fine plants. Price 10 cents each.

\section{Madeira Vine.}

One of the finest and most rapid growing vines in cultivation, with thick, glossy leaves; the flowers are feathery white. Price, 10 and 15 cents each.

\section{Matrimony Vine.}

Chinese Hardy-A vigorous, hardy, climbing plant; rapid grower; covers quite a large space in short time; makes a dense shade and will grow and thrive in any situation, either shade or bright sunlight. Field grown plants, 25 cents each.

\section{Musa Ensete.}

(Abyssinian Banana.)

Large, ornamental foliage, the

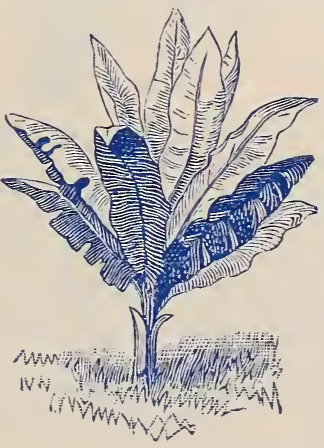
leaves on well wrown plants are two feet wide by six feet long. Giverich soil deeply dug, and water freely ; take up before frost and store in a frost proof cellar. Fine specimen plants, \$2.气̃0 each.

\section{Oxalis.}

The plants are of the easiest possible culture and are fine for baskets.

Rubra-Flower, bright red. Price, 10 cents.

Alba-Color of flowers, white. Price. 10 cents.

\section{Ornithogalum.}

(Sea Onion.)

Strong plants from 2 1-2 inch pots. $1 \tilde{0}$ cents ; 4 inch pots, 25 cents; small plants, 10 cents. 


\section{Pansies.}

There is no flower that gires as much pleasure with as little trouble as the Pansy. Plant them, if possible, in a

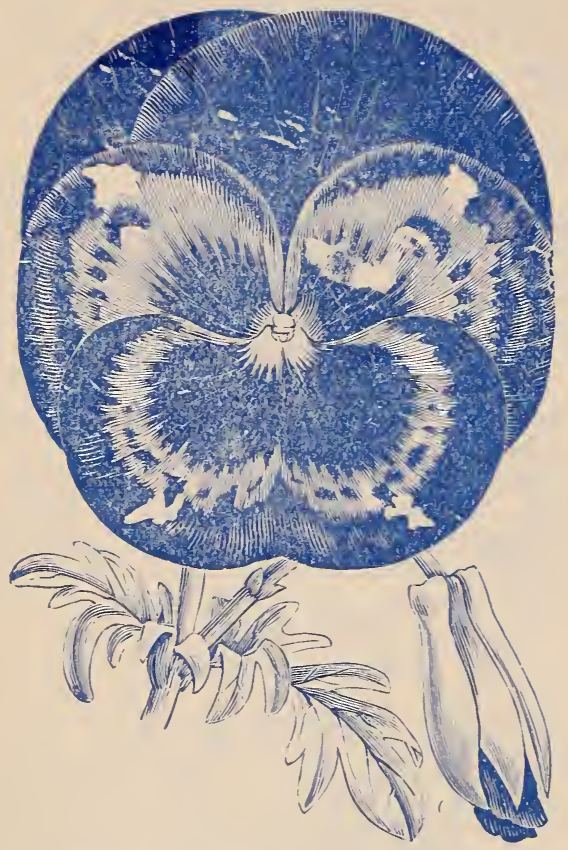

partial shade and see that they do not sutfer for water. They will bloom better if all the flowers are cut off as they begin to fade. We have a splendid collection of Pansies in all the different shades of color, including the celebrated Butterfly and Giant Fancy Pansies. Strong plants from cold frame. that will bloom in April, price, 5 cents each, or 50 cents per dozen. Smaller plants by mail. same price; but cannot accept an order to be sent by mail for less than 50 cents. Be sure to order your Pansies early. The months of April and May are the best, the former being preferalle.

\section{Petunias.}

Mephisto-Double red.

sinou Flute-This is the finest rouble white.

Ethel-White, blotched purple. Price. 10 cents.

One of each for 25 cents.

\section{Pink (Hardy).}

śnnu-A perfectly hardy plant, pro- ducing immense quantities of pure white flowers, resembling the finest Caruations ; a good plant for cemetery planting.

Pleasant's Eye-The ground color a pure white with a crimson eye. Unlike most hardy varieties, it blooms profusely, showing more or less flower's the entire season.

Her Majesty-This charming novelty, which is unquestionably one of the finest of this country, is far ahead of anything yet seen in the war of hardy Pinks. It is a compact and vigorous grower. producing in great profusion flowers of the clearest white. very double, and on long, stiff stems. Delicious clove scented fragrance.

Clumps from open ground, 10 in 14 inches over, each 25 cents. Will bloom first year; pot plants do not.

\section{Pilea, Artillery Plant.}

Arorea-A prettr little plant groming from 6 to 8 inclies high, resembling some of the ferms in general appearance: its graceful drooping habit makes it clesirable for vases or baskets. Price, 10 cents.

\section{Passion Flower.}

Fine foliage and graceful climbing habit. Very peculiar corona-like flowers. but very beautiful and inlike any other flower ; easy to grow, either in window or open ground.

Pfordei-The best for pot culture. as it hlooms when but a foot high. L a rge, handsome, fringed flowers, exhibiting a mingling of

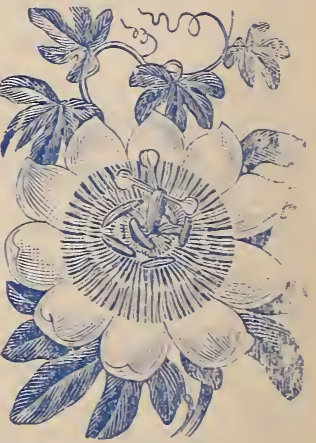
white. pink. brown and blue in its color'ing. making a flower of the most fascinating beauty. Price. 10 ('ents each.

\section{Paeonies.}

The Paeonies are among the showicat and most useful of all hardy plants. Ther succeed well in almost any situation, but flowers will be brighter and finer if planterl in deep. rich, Toam, woll manured. 'The tlowers are of an im- 
mense size, perfectly double and richly colored; are gorgeous when planted alone on the lawn, attracting attention from everyone.

Superbu-An elegant double white of the purest color. Of immense size and queenly splendor. Price, 25 cents.

Magnifica-A delicate soft pink of exquisite shade and great beauty. Free bloomer of excellent merit. Price, 25 cts.

\section{Pelargonium.}

Lady Washington Geranium-These beautiful spring flowering plants are the admiration of all; must be seen to be appreciated.
Mad. Vibert-Fine black, maroon blotches, bordered red, the flower edged with rose. Price, 3 in. pot, 20 cents.

Mis. Robert Sandiford-Grand white variety ; flower large size, well doubled, beautifully ruffled along the edge of the petals and of glistening snow white color. Price, 3 in. pot, 20 cents each.

Madam Thibaut-White, richly blotched and marbled with rose, the upper petals marked with crimson maroon; large white center, immense trusses of large, fine flowers with undulated petals. Price, 3 in. pot, 20 cents each.

\section{Rose Department.}

\section{THE CRIMSON RAMBLER.}

\section{Magnificent Pyramidal Clusters of Rich Crimson Roses. Every Cluster a Perfect Boquet of Roses in Itself.}

This grand Rose improves upon acquaintance; the better it becomes known the more popular it becomes. We have occasionally to modify opinions formed of the value of new Roses, but the "Crimson Rambler" is one that we offer to our customers, after a two years' trial, with greater confidence in its merits. It came to this country heralded as a wonder among flowers, but the most extravagant praises yet bestowed on it fall short of doing it ample justice. Price. 2 year old plants, (budded) 35 cents each; 3 year old plants. (own roots) 50 cents each. Pot plants, 2 inch, 10 cents; 3 inch, 15 cents. It is adapted to the entire country and should be in every garden in America.

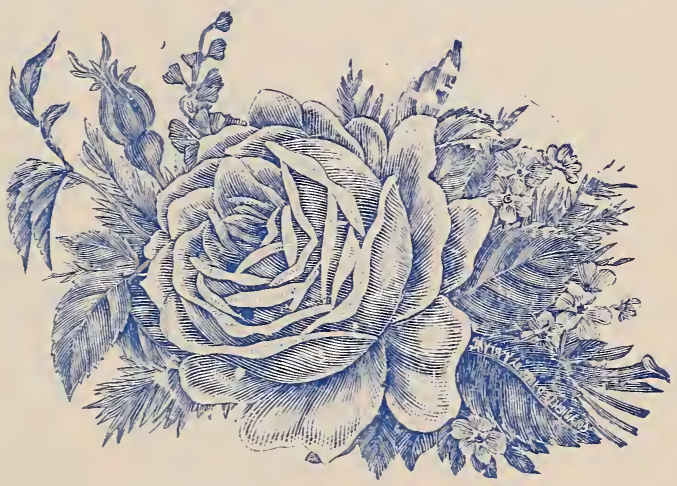

THE YELLOW RAMBLER (Aglaia).

This promises to fill that long felt want. A hardy double yellow climbing Rose. It is perfectly donble, fragrant, and perfectly hardy. It is related to the Crimson Rambler, and like it, blooms in clusters. Price, 1 year old field grown plants, 30 cents. Pot plants, 2 inch, 10 cents ; 3 inch, 15 cents ; 4 inch, 25 to 3 a cents.

\section{THE WHITE RAMBLER (Thalia).}

Pure white; in other characteristics like Aglaia. Price each, 1 rear old field grown plants, 30 cents; 2 inch pot plants, 10 cents ; 4 inch pot plants, 25 cents.

\section{THE PINK RAMBLER (Euphrosym).}

The color is a beantiful lustrous rosy pink; perfectly hardy ; style and"growtb same as Thalia. Price, 1 year old field grown plants, $30^{\circ}$ cents. 


\section{Tea Roses.}

Bridesmaid-This exquisite new Rose is a sport from the old favorite Catherine Iermet. The Bridesmaid retains all the good qualities of the parent, and is very similar in every respect, save color, which is about two shades darker, being a bright. soft pink. which is not affected in color by the weather. Price, 10 cents.

The Bride-This is decidedly the most beautiful white Tea Rose. 'The flowers are very large and double, on long, stiff stems, of fine texture and substance. and last a long time in a fresh state after being cut. making it one of the best varieties for corsage wear or boquets. Price 10 cents.

Perle de Jardins-This magnificent Rose still retains its position as the finest of its color ret introduced, and grows into perfect faror year after vear. The color varies from canary to golden rellow flowers, large and beautifully formed, handsome in every stage of development, from the smallest bud to the open bloom. 'The color, whether light or deep. alwars has a peculiar softness not observed in any other vellow rose; very full and highly perfumed. It is the farorite rellow rose. Price. 10 cents each.

Catherine Merimet-One of the finest roses grown. The buds are rery large and globular. the petals being recurved and showing to advantage the lovely bright pink of the center, shading into light creamy pink. Price, 10 cents.

Bon Silene-One of the best roses ever introduced, and few can equal in freelom of flowering, fragrance or vigor of growth. The flowers are soft crimson fading to pink. It grows rapidly and is highly perfumed. We have had one of these grand roses planted in our greenhouse for about six vears. It is over six feet high and spreads to about the same width. It hears annually from 1 welve to fifteen hundred roses. If you do not buy but one rose, get this one. Price, 10 and 1 o cents.

\section{Hybrid Teas.}

Americun Beruty - As a national rose this undoubtedly stands at the head as a free hlonmer and a strong grower. The first attraction is its fragrance. relicious heyond comparison : second, its great size; third, the profusion of rich foliage that can alwars be found with every bloom: color rich carmine crimson. 'This Rose is undoubtedly the most prolific bloomer out. Price each, 15 cents.

La Fianre-Delicate silvery rose shaded with crimson pink, often silvery pink with peach shading. Very large, very double, superb form. It flowers continuously throughout the season. None can surpass the delicacy of its coloring; fragrance incomparable. Price. 10 and 25 cents.

Dnchess of :1lbamy-This grand variety is a sport from La France. and inherits all the grand qualities which have macle its parent the farorite it is. Its color is a deep, rich rose. It may he kept in the open grounrl all winter if covered with straw or leaves, or it may be potted, and will bloom all winter in a sunny window or greenlouse. Price. 10 and 25 cents.

Meteor-This splendid Rose is admitted one of the lirightest colored and most brilliaut Roses we have. and is highly recommended for bedding and general planting. as well as for growing in pots and conservatory. 'The color is rich velvety erimson. Price, 10 to 25) cents.

sonrenir de Presirtent (rimot-A hrbrid Tea Rose of great promise. It is unquestionably the finest Rose introduced in a decalle. 'The growth is vigorous. foliage dark green and very handsome. but the glory of the variety is in its flower. It is rosy flesh, very soft at the center. sharling lighter at outer end of the petals: shape and style same as La France. Price, 2 1-2 inch pots. 15 cents.

Kariserin Ammsta Tirtoria-A soft. pearly white. lightly tinted with lemon in the (enter: remarkably fragrant: a strong. healtliy grower. witl hold. beatiful foliage. The llowers are horme on long stems. Price, 15 cents each.

\section{Polyanthus Roses.}

C'othilde šnmpert (Polyantha Tea) The plant grows from 16 to 18 inches high. and is an excellent sort for bedling. 'The flower is large, very full and finely imbricated: the outer jetals are pearly white. shading to a line rosy 
pink center. Very free flowering and nicely scented. Price, 10. 15 and 25 cents.

Miniature-This is the smallest of all Roses, but perfect in form; regular, compact, fairy-like flowers. fully double and very fragraut; Howers in wreaths and clusters seem to cover the whole plant: color, white. Price. field grown plants, $2 \tilde{\text { cents. }}$

Littie Pet-A very charming fairy Rose; flowers of perfect form. very donble and full: pure creamy white, sometimes delicately tinged with salmon rose. Price. 15 cents.

Mermosa-A beautiful and useful Rose; blooms in fine clusters: medium size: very double; beautiful clear rose: constant bloomer: early. P'rice, 10 ('ents each.

\section{Pillar Roses.}

Empress of Chind-This remarkable climbing Rose should find a ready welcome as its wonderful merits. which we have thoroughly tested, stamp it as the most valuable and noteworthy Rose of its class introduced for many years. It is a true perpetual bloomer-commences to flower in May and continues until late in the fall. Very profuse: flower pink, semi-double. Price, field grown plants, only 25 cents.

Mary Washington-Its flowers are of merlium size, pure white, perfectly rlouble to the center, sweet and borve in enclless numbers all summer. It is a vigorous and rapid grower. and must at nince become a general farorite. It makes a great profusion of fine buds, which are borne on long stems and usually in large clusters. One plant of Mary Washington will produce more flowers and buds than a dozen ordinary Roses. Price, 2 in. pot plants, 10 cents each : 3 in. 15 cents : 4 in. 25 cents.

\section{Noisette.}

(Tender Climbing liose.)

Glorie de Digon-Very laroe, double, rich canary amber color; hardy with gool protection. Price. 15́ cents each.

\section{The Memorial Rose.}

Rosa Wirhuriana-A beautiful single Rose from Japan. Blooms in clusters on the ends of short branches during July and August; flowers fragrant, single, ptire white. with yellow stamens, followed in fall and winter with bright red fruit. Foliage dark shining green, almost evergreen; prostrate, trailing habit. and soon forms a dense mat or covering. Valuable for covering low walls, banks or rockeries, and for corering graves in cemeteries. It is perfectly hardy. Field grown plants. 2 years old. 25 cents each; 3 in. pot plants, 15 cents.

\section{Prairie Roses.} (Climbing.)

Baltimore Belle-Small, but compact. and perfect flowers : borne in very large clusters; blush white.

Prairie Queen-Flowers of medium size, globular form: bright, rosy-red, changing to brighter as flowers open; strong, rapid growth. Price, 4 year old plants, 35 cents each.

\section{Hybrid Perpetual Roses.}

Gen. Jacqueminot-This is without doubt the best hardy, dark red Rose grown ; strong; field grown.

Panl Teyron-A grand Rose with immense double flowers, probably the largest grown; bright shiniug pink.

Magma Charter-Pink, suffused with rose.

Dinsmore-This fine variety possesses all the desirable qualities of a bedding Rose-good color, fine form, a profuse bloomer, and stands the rigor of our Northern winters without protection. The flowers are large, double and deep crimson.

Imna de Diesbach-Dark rich pink: immense size: one of the finest hardy Roses.

John Hopper-Bright rose with carmine center, large and full; esteemed by all who grow it as of the highest order.

Madam Mason-Brilliant pink, shading to carmine crimson: very fragrant.

Price of above 1 year old field grown plants, 25 cents each ; 5 for $\$ 1.00$; per lozen. \$2.00; 2 1-2 in. pot plants, 10 cents ; 3 in. pot plants, 15 cents.

Margaret Dickson-White ; extra large flower of fine substance, strong, vigorous growth. Price, pot plants. 15 cents each.

Persian Yellou-The old fashioned early garden líose. Price, 3 õ cents. 


\section{Rosemary.}

(German.)

Rosemary-A low growing half hardy evergreen: very pungent odor. Price, 10 cents.

\section{Rudbeckia.}

(Golden Glow.)

A glorious plant, and one that should find a place in every garden. Without question the best hardy plant introduced in many years. It is of fine habit and rigorous growth, attaining a height of from 4 to 6 feet and begins to flower early in the season, and continues until late in the fall. The flowers are produced in enormous quantities on long stems, and resemble a fine double golden-rellow cactus dahlia; and as a cut flower for rases. etc., it has no equal. Price, 20 cents each.

\section{Stephanotes.}

Floribunda-One of the most charming hot-house climbers. growing rapidly. with long, glossy, deep green foliage. and producing clusters of pure white. waxy and deliciously fragrant flowers: well adapted to window gardening. Price. 25 cents each.

\section{Stevia Serata.}

A white, winter blooming plant, fine to word with cut flowers. Price, 10 cents each.

\section{Salvias.}

(Scarlet Sage.)

S. Compacti-A drarf scarlet rariety. forming a compact bus s about 15 inches $\mathrm{high}$ and 24 inches across. One of the finest varieties ret introd uced, for either summer or winter bloom. Price. 10 cents.

\section{Smilax.}

A fine decorative plant, largely used for that purpose. Price. 5 and 10 cents.

\section{Sanseveria Zealanica.}

A heautiful plant, splendidly adapted for the decoration of the clrawing rooms and halls, as it stands drought and dust with impunity. The leaves grow to a length of 2 to 3 feet, and are beautifully striped crosswise with broad, white rariegation on a dark green ground. It is a rare and beautiful plant which should be abundantly grown for posi. tions out of the reach of sunlight. where other plants will not thrive. Price, 25 to 50 cents: specimen plants, $\$ 1$ each.

\section{Swainsonia Galegifolia Alba.}

A plant which is becoming very popular for house culture. Foliage as graceful as an Acacia: flowers pure white. produced in sprays of 12 to 20 flowers each. and resemble Sweet Peas. It is of the easiest culture and ever blooming. Price. 10 cents.

\section{Tube Rose.}

The Tube Rose is a beautiful pure white. wax-like, very sweet scented. double flowers. growing on tall stems, each stem bearing a dozen or more beautiful flowers. Select bullos. $\tilde{0}$ cents each, or 50 cents per dozen.

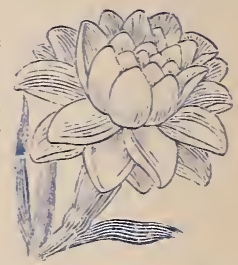

\section{Tradescantia Discolor.}

Lpright. herbaceous plant. large dark green leaves. under side purple. very ornamental ; first-class for haskets, etc. Price. 10 cents.

\section{Tradescantia.}

(Wandering Jew.)

A beantiful basket plant of rining habit: three rarieties. Price. 10 cents each, or 3 for 25 cents.

\section{Tropaeolums (Nasturtion).}

$$
\text { (Single.) }
$$

The plants are quite desirable for house culture or for the garden: ther are always in bloom. Te have a large stock of the dwarf varieties. of various colors, raised from seeds. Price. 5 cents each : 50 cents per dozen.

\section{Tropaeolums (Nasturtion).}

(r)ouble.)

Darkness-The flowers of this are very double and of a dark maroon color, a beautiful and attractive trailing plant. Price. 10 cents each ; 3 for 25 cents.

\section{Vincas (Trailing).}

Majoi-A beautiful rariegated trailing plant. well adapted for baskets ami 
vases, leaves glossy green. broadly margined with pure white. Price 10 cents.

Harrisonii-Very strong growing variety, similar to the above in habit: margin of leaves a rich dark green. Price, 10 cents.

\section{Violets.}

Marie Lomise-Deep violet hue : very fragrant and free flowering. Price, 10 cents each.

\section{The Californi Violet.}

Plant vigorous and absolu t ely free from disease; Howers s in gle. immense in size ; color, velvet purple (does not fade) ; fragrance intense, flowers borne on strong stems ten to four-

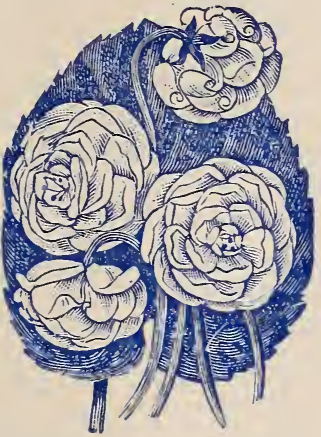
teen inches in length. Last season several hundred flowers were picked from a single plant. Price, 15 cents.

Suraniy White-The best white Violet yet attained. Price, 10 cents each.

\section{Verbenas.}

Verbenas love plenty of sunshine, moisture and rich soil ; in fact the ground can hardly be made too rich for them. Each, 5̃ cents ; per dozen, כ0 cents.

\section{Wisteria.}

A perfectly hardy, rapid growing vine, suitable for porches or any place where a hardy vine is desired.

Wisteria Ciencil-Has elusters of beautiful blue flowers; a very rapid grower.

Wisteria $A l b a-$ Same as above, except flowers are white. Price, 25 cents each.

\section{Hardy Grasses.}

Eulatia Japonica Zebrina-The long blades are marked with broad yellow bands across the leaf; makes a very attractive specimen plant for the lawn: 4 to 6 feet high. Strong plants, 25 cents.

Eulatia Gracillima-This a grand addition to the ornamental grasses; of compact habit, very narrow foliage, of a bright green color with a silvery midrib: 4 to 6 feet high. Strong plants, 2 õ cents.

\section{Yucca Filamentosa.}

Perfectly hardy and easy grown; very odd and beautiful. The stem on which the flowers are borne is thrown up in July, and forms a perfect pyramid of creamy white, bell-shaped flowers. Very picturesque effects are produced when planted in groups on the lawn. Price, 25 to 50 cents.

\section{Bulbs.}

We always carry a full line for spring and fall planting. Prices on application.

\section{PALMS.}

\section{Kentias.}

Balmorena-Six inch pot, \$2.00.

Fosteriana-Two and one-half to 3 feet, $\$ 3.00$.

Phoenix Coraensis-Five inch pot. $\$ 1.00$.

Isatana Barbonira (Chinese Fan Palm) -Five inch pot, $\$ 1.25 ; 6$ inch pot: $\$ 1.75 ; 7$ inch pot, $\$ 2.00$ to $\$ 2.50$.

Cocos Weddeliana-Four inch pot, $\$ 1.50$.

Cycas Revoluta-Six inch pot $\$ 2.50$ to $\$ 3.00$.

\section{FERN.}

Sruord Fern-25 cents to $\$ 1.25$ each. 


\section{Cut Flowers.}

\section{Give Us Your Order.}

We have greatly enlarged our Cut Flower department and are now ready to furnish all kinds of Cut Flowers on short notice for weddings, parties, balls, dinners, funerals, etc., with prices as follows, except at Christmas, Easter, and such other special occasions, when they will be higher. Prices subject to change without notice.

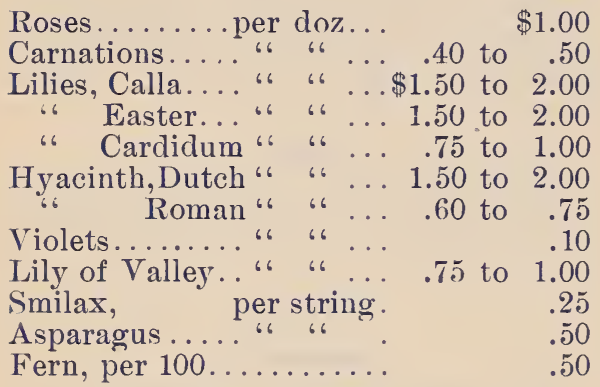

FUNERAL DESIGNS.

We are prepared to do all kinds of de-

sign work on short notice, with prices as follows :

Wreaths............ \$2.00 to $\$ 5.00$

Crosses............. 1.50" " 5.00

Anchors ........... 1.50 " 5.00

Pillows ............. 2.006" 10.00

Sickles............. 1.50'" 5.00

Harps ............. 2.50" 5.00

Lyres ............... 2.50" 5.00

Stars .............. 2.00" 5.00

Gates Ajar............ 5.00 “6 25.00

Broken Wheel......... 5. 5.00"6 10.00

6" Column ........ 5.00" 10.00

Doves (white) ......... 1.50 " 2.50

We keep on hand all kinds of emblematic designs for secret societies. Baskets and designs for closing of school at $\$ 2.00$ to $\$ 10.00$. Our system of packing is perfect and flowers and designs can be sent any distance. Parties who order flowers and want them on return train should use special delivery stamp, telegraph or telephone. Long distance telephone No. 21.

\section{SPECIAL NOTICE.}

\section{We Lead, Others Follow,}

As to quality, price and quantity. We are enabled to sell plants at the quoted prices, only by raising and selling them in large quantities. We claim that we do raise and sell more plants than all the plant raisers in Carroll or adjoining counties put together. To obtain our plants you must either come or send direct to us, as we positively will not have our plants for sale at any of the stores in Carrollton. 


\section{Vegetable Plants.}

\section{Prices Cheaper Than Ever Before.}

We have twenty acres in garden. therefore we make a specialty of raising regetable plants, raising, setting and shipping hundreds of thousands of plants 'annually. We ship large quantities of plants to distant states and territories. Our system of packing is so complete that we rarely erer hare any plants damaged. All vegetable plants sent out by us are raised from the same seed that we use ourselves; in fact we do not offer any plants for sale that we do not set out large quantities from the same beds in our own garden. All plants are raised from the best of seeds, regardless of cost of seeds. Early cabbage should be set out in April-the sooner the better; second early, about May lst: late cabbages from May to the last of July.

\section{Cabbage Plants.}

Early Jersey Wakefield-This is, without doubt, the best early cabbage grown. The variety we use for early planting; every plant forming a large. solid head. Strong. stalky plants ready April 1st. Per 100, 40 cents; after May 1st, at 30 cents per 100 ; per $1000, \$ 2.00$.

All Serson-This excellent strain of early Drum Head cabbage is as early and good as the Early Summer, and growing a thirr to half as large again. As the name indicates, it can be planted at all seasons, and makes both a splendid early and late variety. It forms a fine, large head of superior variety, not bursting after heading. Strong plants ready April 1st ; per 100, 40 cents ; after May 1st, per 100, 30 cents ; per $1000, \$ 2.00$.

Henderson's Summer--For second planting we have never found any superior to this. It stands the hot sun well and usually forms large, solid heads of fine flavor. Good, stalky plants on and after May 1st, 30 cents per 100 ; per 1000, \$2.00.

Premium Late Flat Dutch-(Late). There may be other varieties of late cabbage just as good as this ; still, in our fifteen rears' experience in market gardening we have found none that we considered any better; plants ready from May 1st to July 10th; per 100,25 cents : per $1000, \$ 1.75$.

\section{Cauliflower.}

Early Tarieties-Highly esteemed by market gardeners for its earliness and reliability as a sure header. It grows on a robust stem, and produces magnificent white heads of fine quality. Plants during April and May (only) per 100, \$1.00.

\section{Celery.}

Giant Pascal-The latest and best variety of celery. It is a selection from the frolden Self-Blanching. and adds to the general goorl qualities of its parent, goorl keeping qualities. The stalks are very large, thick, solid, crisp and of a rich. nutty Havor, free from all trace of bitterness. Price, 40 cents per 100 .

Henderson White Half Durf-The leading rariety for market gardeners. When blanched it is of a yellowish white, entirely solid and of nutty flavor. Price, 40 cents per 100 .

IThite Plume-Each year adds to the popularity and value of this variety. It requires very little earthing up to blanch it: as a celery for fall and early winter use it is unsurpassed. Price. 40 cents per 100 .

\section{Pepper.}

Larye Bell or Bull Nose-A very large sort of square form. tapering to a point; mild. thick and hard: suitable for filling with eabhage. etc. and for a mixed 
pickle. Less pungent than most other sorts, and one of the earliest varieties. Price, per dozen, 10 cents.

Long Red Cayenne-Long, red, hot and pungent; dwarf growth. Price, 10 cents per dozen.

\section{Tomato Plants.}

We raise large quantities of the leading varieties; can supply them by the thousand if wanted. Ready to set out on and after May 10th. Standard varieties -all too well known to need any description.

Early-Atlantic Prize, Dwarf Late-Turner's Hybrid, Perfection, Champion, Buckeye, State, Stone.

Beauty, Ponderosa, Matchless.

Price, per dozen. 10 cents ; per 100, 60 cents.

\section{Asparagus.}

Palmetto-Two-year-old roots, $\$ 1.50$ per $100 ; 1$ year, $\$ 1.00$ per 100 .

Barr's Mammoth-One-year-old roots, $\$ 1.00$ per 100 .

Columbian Mammoth-White-One-year-old roots, $\$ 1.00$ per 100 .

\section{Rhubarb (Pie Plant).}

We have a fine stock of Rhubarb, strong divisions. Price 10 cents each; 3 for 2 cents; $\$ 1.00$ per dozen.

\section{Sweet Potato Plants.}

Of these plants we raise large quantities and can furnish them in most any quantity desired, of the following varieties, ready to set out on and after May 10:

White Brazilian-We consider this one of the best, both in quality and productiveness, although a poor sprouter. Price, 30 cents per 100 .

Southern Queen-A white potato of strong growth and a good yielder. Per 100,20 cents ; per $1000, \$ 1.75$.

Yellow Jersey-A universal favorite with everyone; a splendid potato. Per 100,20 cents ; per $1000, \$ 1.75$.

Red Jersey-Same as above, only the potato is red. Per 100, 20 cents; per $1000, \$ 1.75$.

Red Bermuda-An enormous yielder of pinkish red potatoes; not uncommon to raise potatoes that weigh 7 pounds each. Per 100, 20 cents; per 1000, \$1.75.

Black Spanish-One of the best potatoes grown. Red jacket, white meat, very mealy and rich flavor; one of the best keepers. Per 100,20 cents; per $1000, \$ 1.7 \dot{\text {. }}$.

\section{Raspberries.}

Always plant Black Cap Raspberries in the spring. The red varieties can be planted in the spring or fall.

Palmer-The standard early berry: gets ripe before strawberries are gone. Price, 10 cents each; 3 for 25 cents, or 5̃0 cents per dozen prepaid; $\$ 2.00$ per 100 .

Kansas-Large, early berry; ripens sooner than Palmer. 40 cents per dozen. prepaid; or $\$ 2.00$ per 100 .

The Columbian (New)-A purple berry, of the greatest value. Vigorous, hardy and prolific. Do not omit this berry from your order. 10 cents each; 40) rents per dozen prepaid; $\$ 2.00$ per 100 .

Cuthbert-Red berry; the standard of its kind. 40 cents per dozen, prepaid ; $\$ 2.00$ per 100 .

Golden Queen-A sport from Cuthbert, but has yellow berries. 40 cents per dozen prepaid, or $\$ 2.00$ per 100 .

Loudan (New)-Claimed to be the finest red herry ever introduced. Our stock of Loudans is direct from the introducer. 10 cents each; 50 cents per rlozen prepaid ; $\$ 3.00$ per 100 . 


\section{Blackberries.}

Western Trimmili-Very hardy and a splendid bearer: ripens with Snyder. Per clozen. 00 cents.

Erie-One of the largest of herries; hardy, and a heavy bearer. Per dozen. 50 cents.

Elderado (New) - All who have tested it are loud in its praise. Per clozen, 50 cents.

Early Harrest-The money maker among Blackberries; ripens two weeks before any other: was ripe here last year June 14 th. 40 cents per dozen; $\$ 2.00$ per 100 .

All Raspberries and Blackberries priced per single plant will be sent postpaid, ne per 100 rit your expense.

\section{Strawberries $==$ When to Plant.}

By all means in the Spring; never late in the Fall. Sometimes they do very well set out in July or August. but do better in Spring. As soon as the ground can be worked. get the ground in fine condition; plant the rows three feet apart and the plants eighteen inches apart; give thorough cultivation, and do not let them get too thick-keep part of the runners cut off, at least.

Those marked (P) have pistalate or imperfect blossoms and must be planted near some variety with perfect blossoms to fruit them. 'Those marked (B) are bisexual or perfect blossom, and will do well by themselves.

Send your orders early. as your plants will do better if set out early.

\begin{tabular}{|c|c|c|}
\hline Bedder Wood, B. & $\begin{array}{l}12 \text { by Mail, } \\
\text { Post Paid: } \\
\text {. } \$ .25\end{array}$ & $\begin{array}{c}100 \text { by Express } \\
\text { Not Paid. } \\
\$ .50\end{array}$ \\
\hline Bubach, P....... & $\ldots \quad .25$ & .50 \\
\hline Brandrwine, B.... & $\ldots .25$ & .50 \\
\hline Bisel. P. . . . . & .25 & .50 \\
\hline Jessie, B. & .25 & .50 \\
\hline Crescent, P. & .25 & .50 \\
\hline Lovett, B . . . & .25 & .50 \\
\hline Warfield, P.... & .25 & .50 \\
\hline Edgar Queen. P... & .25 & .50 \\
\hline Great Pacific. P. & .25 & .50 \\
\hline Princess. P....... & .25 & .50 \\
\hline Sharpless, B... & .25 & .50 \\
\hline Annie Laurie, B. . . . & .25 & .50 \\
\hline Marshall, B..... . & .25 & .50 \\
\hline Gandy, $13 \ldots \ldots \ldots$ & .25 & .50 \\
\hline Mitchell's Early, B & $.20 \check{2}$ & .50 \\
\hline Glen Mary, P. . . . . & $.2 \tilde{0}$ & .50 \\
\hline
\end{tabular}

Plants per $1000, \$ 4.00$ : 500 at 1000 rate.

Strawhery plants ordered for July or August delivery, double above prices.

\section{Gooseberries.}

Red Jacket (New)-Very prolific, hardy and free from mildew. A strong grower. Berries very large and of superior quality. 2 year old plants, price each. 15) cents.

\section{Currants.}

Cherry-Large, red: quite acid; bunch short; plant vigorous and productive, well known variety. Price each, 10 cents; per dozen, 75 cents.

Tictoria-Red : very large and productive. Price each, 10 cents; per dozen, 7ò cents. 


\section{Garden Seeds.}

Owing to the numerous calls for Garden Seeds we have added a few of the leading rarieties only-in fact only such rarieties as we have used ourselves in our own garden, and that have proven to be the best. The buy all our seeds from one of the oldest and most reliable seed houses in the country. While we exercise the greatest care to hare all the seeds true to name. if any should prore otherwise we will replace them or refund the money paid for them; but in no case are we liable for the crops.

\section{Dwarf or Bush Beans-Green Podded Sorts.}

Early Broun Moleaul-Hardiest of any, eren resisting a slight degree of frost successfully : very early and prolific. Quart. 25 cents.

Improved or Extra Early Round Pod Red Speckled Talentine-Hardy and vigorous, upright in growth, pods being held well up from the ground, early ancl remarkably uniform in ripening. Quart, 30 cents.

\section{Wax Podded Sorts.}

Duarf Prolific German Black Tax(Stringless) - In improved strain of the old German Black ITax beans. Porls perfectly round, straight. long and an even rich. waxy color. Quart. 30 cents.

\section{Limas.}

Buipee's Large Bust Limas-A bush form of the true Large Lima. The plants are uniformly dwarf. but enormously productive: single plants under favorable circumstances often rielding from 100 to 250 pods. Quart. 35 cents.

\section{Pole Beans.}

Red-Speckled Oial-seeded Cut-Shont Corn Field-This is a climbing greenpodded Bean, used in the South for planting to corn. and hence known in some localities as a Cornfield Bean. of which there are nanv varieties. this being one of the hest. It is very productire. and for table purposes. used as a snap. is of an excellent quality : porls greeu. half round and succulent. Quart. 35 cents.

\section{Sweet or Sugar Corn.}

Extra Early IThite Col Cory. Sireet -This variety is undoubterlly the earliest of all. and the very best extra early Sweet Corn. Quart, 20 cents.

Country Gentlemun. or Impioced Shoe Peg. Sireet-Second early. The sweetest and most tender of all siweet Corns. This is not only true, but in addition to this the Country Gentleman is one of the most productive sorts. the stalks averaging three ears, sometimes as many as five. Quart, 20 cents.

Storell's Erergreen Sreet-Standard late variety. General planting. 'I'his variety is more largely planted than any other. being the general farorite with canners and market gardeners for late use. It is very productive. the ears are of large size. orains deep. exceptionally. tender and sugarr. and remain for a long time in an eclible condition. Quart. 20 cents.

\section{Peas.}

Plants Ertra Early-This is the most profitable. and superior to any other extra earls Pea, maturing from forty to forty-fivedays from germination. Quart, 2.5 cents.

Alaska-The earliest blue pea, very uniform in growth. The dark green color of the pods makes it extremely desirable. About 2 feet high. Quart. 20) cents.

stropstiire Hero-For general merit this is without an equal. It is a second early wrinklerl variets. about 21 . feet in height and is covered from top to bottom with long. handsome poils. Quart, 20 cents.

\section{Dwarf Early Peas.}

Americun Ionder-Verr early: 10 to 1.2 inch. Quart. 25 cents. 
IIorsford's Murket Gurden-A grand wrinkled variety. It is a prolific bearer, and rields abuindantly. Pods. medium size, numerous and fill with peas of a delicious sweet flavor. Quart. 20 cents.

\section{Beet.}

Early Eqyptiun Dark Red-The well known favorite: the standard early market sort: color very deep red : tender and sweet. Ounce, 10 cents.

Mitchell': Perferted Eurliest Dark Red -It is nearly as early as the Egrptian, but larger. of fine dark red color. tender and sweet at all times, whether old or roung. It will produce a crop in six weeks. Ounce, 10 cents.

\section{Cabbage.}

Early Jersey Wakefield-The best early cabbage in cultivation. Sure to head. Ounce, 2 ó cents; $1-41 b ., 75$ cents.

Henderson's Early Summer-The earliest large heading Cabbage: growth compact, so that it may be set as close as the smaller sorts. Heads large, Hat. Ounce. 20 cents: $1-4$ lb.. 60 cents.

.17l Season. or sureliead (True)-This excellent strain of early Drumhead Cabhage is as early and good as the Early Summer. and growing a third to half as large again. As the name inclicates. it can he planted at all seasons. Ounce. 20 cents: $1-41 b . .60$ cents.

\section{Preminm Late Flat Dutch-Select} Qunlity-The standard winter variety, low growth, heads large. bluish green. round. solid. hroad and Hat. Onnce, 20 ('ents: $1-4$ lb).. (i0 cents.

\section{Carrot.}

Early IIralf Long Scarlet. Stump Ronted-An excellent variety for market gardeners: color scarlet: good for shallow soils. Ounce, 10 cents.

\section{Cucumber.}

Extra Long Write spine-This variety grows iu to 12 inches long, very straight and handsome. When 5 to 6 inches long good for pickles. (nunce, 10 cents.

\section{Lettuce.}

Black Seeded Simpson-We consider this the hest early sort. Unnce, 15 ('ents.

Fround Rapids-A little later than
Simpson. Very fine and crisp; splendid market variety. Ounce. 15 cents.

\section{Mustard.}

Broun-More pungent than white. For greens or salad sow broadcast early. Ounce. 10 cents.

\section{Onion.}

Large Red Tethersfield-This is the farorite white meated onion. Ton mell known to need description. Ounce. 20 cents.

Large Red Globe-Matures nearly as early as the flat sorts, and is particularly mild and tender. Ounce, 20 cents.

Extra Early Thite Pearl-In many respects the most remarkable Onion ever introduced. Earliest of all. Pearly white, waxy, translucent. Form flat and broad. Fine for pickling. Ounce. 25 cents.

\section{Okra or Gumbo.}

Improved Ducinf Gieen-Early and very productive: smooth pods. Uunce, 10 cents.

\section{Parsley.}

Myott's Gamishing-Finely curled and moss-like. Ounce, 10 cents.

\section{Parsnips.}

Iarge Sugai-Roots comparatively short, ending somewhat abruptly with a small tap root. Ounce. 10 cents.

\section{Raddishes.}

Earliest Eurfoit-I)ark red; round. Ounce, 10 cents.

Plitadelphia 17 Tite Box-Popular early round, white. Ounce. 10 cents.

Eurly Scarlet Turnip-Small, round, very quick growth. Ounce, 10 cents.

Lady Finger-Early. long, white. Ounce. 10 cents.

Warket Gardener's Long Scarlet-An extra early. improved rariety. Ounce, 10 cents.

St. Louis White Summer-The most popular summer raddish grown. Ounce. 10 cents.

Irlite Summer Trmip-A standard sort. turnip shape, white and crisp. ()unce. 10 cents.

White Giant situtgart-Will produce roots of excellent quality in six weeks. Ounce. 10 cents. 


\section{Salsify}

Scorzonera-Or Black Oyster Plant. Roots black before cooking. Ounce, 15 cents.

\section{Spinach.}

Round Thick-Leaved-A standard sort. Very large, thick leaves. Ounce, 10 cents.

\section{Turnip,}

Extra Early Purple Top MilanOunce, 15 cents.

\section{FLOWER SEEDS.}

\section{Nasturtion.}

Tall Mixed-Ounce, 10 cents.

Duarf Mixed-Ounce, 10 cents.

\section{Sweet Peas.}

Eckford's Fanry Selert MirerlOunce, 10 cents.

Seeds priced at ounce rates may be sent postpaid, but extra charge will be made for quart measure.

\section{PURE JAPANESE GOLD AND PEARL FISH.}

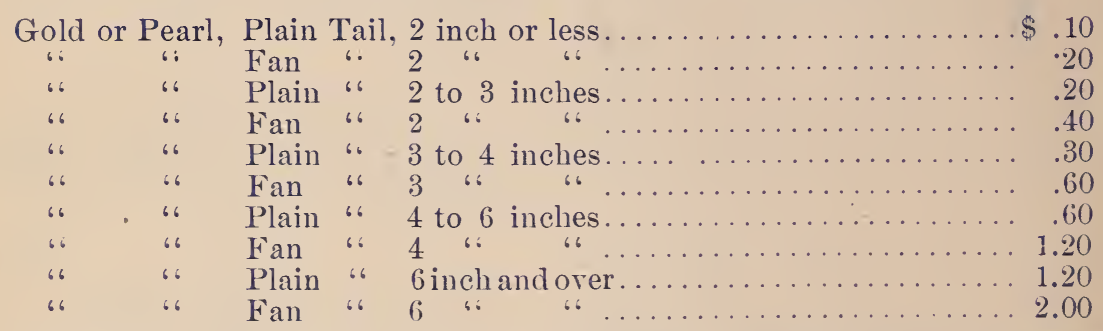

Comet Fish, long tail, prices on application. Special prices on Pearl and Gold Fish in large quantities, on application. No order for less than 50 cents will be considered at above prices.

The Pearl Fish are pure white.

Pails for shipping, extra, at the following prices:

One-half gallon bucket. 10 cents ; 1 gallon bucket. 15 cents : 2 gallon bucket. 25 cents ; 3 gallon bucket, 35 cents : 4 gallon bucket, 4 5 cents ; 6 qallon bucket, 60 cents.

You can ship one dozen small fish to each gallon. soliciterl.

We are prepared to furnish Crappie for stocking ponds. Correspondence 


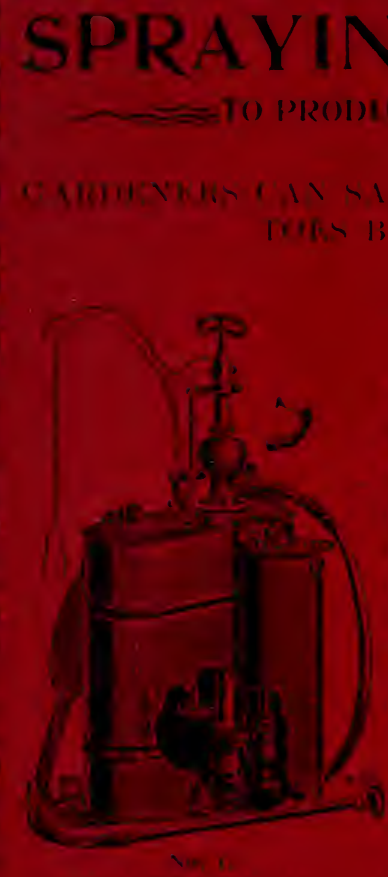

\section{(}

\section{VE(jETABLES}




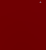

